\title{
After Postmodernism: Reactionary Tribalism ${ }^{1}$
}

\author{
Robert J. Antonio \\ University of Kansas
}

\begin{abstract}
Revived Weimar-era "radical conservatism" and fresh "New Right" and "paleoconservative" theories offer a radical cultural critique of global capitalism and liberal democracy. Expressing a broader retribalization and perceived failure of modernization, their defense of communal particularity attacks the multicultural nation-state, liberal rights, and universal citizenship. This essay links reactionary tribalism to a recurrent 20th-century theoretical tendency, the "total critique of modernity"-a fusion of oversimplified Nietzschean and Weberian ideas. Historically, total critique has promoted convergence between right and left, such as the current overlapping facets of "radical conservatism" and "strong-program postmodernism." Total critique counters the "historicist" method of "internal critique" and the "communication model" characteristic of reflexive social theory. The discussion uncovers the mediating role of social theory in the problematic relationship of science and partially disenchanted public spheres in plural, democratic cultures.
\end{abstract}

\section{THEORIZING SOCIOCULTURAL RUPTURE: SOCIAL THEORY AND MODERNITY}

Not ideas, but material and ideal interests directly govern ... conduct. Yet very frequently the "world images" ... created by "ideas" have, like switchmen, determined the tracks along which action has been pushed by the dynamics of interest. (Max Weber [1922-23] 1958c, p. 280)

At the end of "Objectivity' in Social Science and Social Policy," Max Weber ([1904] 1949a, p. 112), perhaps reflecting on the roots of his own

\footnotetext{
${ }^{1}$ Many thanks to David Smith for several incisive critiques of earlier versions of this manuscript and to Chip Berlot and Göran Dahl for conversations and exchanges on this topic over the years. Alessandro Bonanno, Lourdes Gouveia, Eric Hanley, Jack Vengelers, Robert Kent, and Cotten Seiler also have been helpful. Three AJS reviewers provided excellent internal critiques that contributed substantially to this article. Direct correspondence to Robert J. Antonio, Department of Sociology, University of Kansas, 716 Fraser Hall, Lawrence, Kansas 66045-2172.
}

(C) 2000 by The University of Chicago. All rights reserved.

$0002-9602 / 2000 / 10601-0002 \$ 02.50$ 
excursion into the philosophy of social science, declared that "when the atmosphere changes ... and the road is lost in the twilight" new standpoints are sought "from the heights of thought." He was speaking of moments of sociocultural rupture, which undermine the efficacy and legitimacy of established ways of doing and knowing. At these times, he implied, the background understandings of everyday practice and established institutions, including science, become visible and contestable; the tacit "value-ideas" that define certain types of knowledge as "worth knowing" and, thereby, shape science's directions shed their taken-for-grantedness and are subject to reflection, criticism, and debate. Weber and other first-generation modern theorists addressed an epochal transformation generated by capitalist development-that is, the rise of mechanized industry, the bureaucratic state, and urban mass culture. As Marx and Engels asserted famously, they faced a condition where "all that is solid melts into air" ([1848] 1976, p. 487). Modern theorists' "historicist" theorizing fit the emergent secular worldview, posing normative standpoints and framing arguments about the "value" of divergent developmental trajectories on the basis of sociological conditions and consequences. Their fresh world images later contributed to fateful shifts of the sociocultural and political "tracks."

Modern theories gave impetus to new social movements and fresh policy regimes as well as to antimodern countercurrents. Competing with other visions, including hegemonic ones, their impacts were not immediate. Many of the theories were ignored, but some were later taken up by specific strata, movements, and parties. During the World War I era and the hard times that followed, the new theories' divergent directions crystallized into fresh versions of right and left and had significant human consequences (Hughes 1977; Kloppenberg 1986; Lepenies 1988). Karl Mannheim held that these normatively oriented approaches often posed "utopian" visions, expressing "premature truths" that "transcend" and threaten to "shatter" the sociocultural orders in which they are nestled. Although starting as "wish fantasies" of individual "forerunners," he argued, they are sometimes made "effective" or are translated into "political aims" by specific carrier strata and popularized by "ascendent" groups. ${ }^{2}$ In his view, however, the strata and groups that transform utopias into realities are not known with any certainty until after they have had substantial impact. To study potentially effective or emergent utopias, Mann-

${ }^{2}$ Speaking of the bourgeois idea of "freedom," Mannheim asserted that "it was in part a real utopia, i.e., it contained elements oriented towards the realization of a new social order which were instrumental in disintegrating the previously existing order and which, after their realization, did in part become translated into reality" ([1936] 1955, p. 203). 
heim implied, requires analysis of how well they engage "currents already present in society" (i.e., imminent changes, crises, conflicts, movements) that open hegemonic views to challenge (1955, pp. 193-94, 203-5).

The types of theory capable of representing Weberian world images or Mannheimian utopias were later eschewed by post-World War II sociologists as "armchair philosophies," too broad for empirical testing, and, more recently, by postmodernists as retrograde "grand narratives," which "elide difference." But new approaches, reminiscent in breadth and normativity to first-generation modern theories, have reemerged in interdisciplinary and transdisciplinary spaces and have generated intense public debates as well as sharp splits within specialized disciplines, including sociology. Similar to the earlier theories, the new ones occupy space between science and philosophy. Their sweeping historical and epistemological discourses debate the normative directions or the "value" of different types of sociocultural life and knowledge. Although often employing scientific research findings and middle-range concepts, these theories go beyond "sociological theory" as strictly construed and are better conceived of as "social theory." As Donald N. Levine holds, social theory is a "metascientific enterprise," arising from the long-standing concern with the "problem of modernity," posing "questions that science may not answer but which we feel compelled to pursue nevertheless," and providing a "secular" and "dialogical" alternative to absolutist or transcendental normative arguments (1995, pp. 306, 317-28; see also 1997). As implied by Levine, social theory "historicizes" normative issues, opening them to sociologically informed public debates, which fit and nurture plural, disenchanted democratic culture. However, social theory is still an emergent, incomplete project manifesting the ongoing reflexive, democratic side of Enlightenment thought. By contrast, my analysis of "reactionary tribalism" probes an antihistoricist tradition, emphasizing reenchantment and dedemocratization. Grasping this theoretical and sociocultural alternative will help clarify the broader significance of modern theory and its entwinement with Enlightenment and democracy. ${ }^{3}$

I explore how the European "New Right" and North American "paleoconservatism" counter the sociological presuppositions of modern theory, especially its keystone "communication model." Although still marginal to public life in most democracies, these approaches address critically neoliberal globalization and cultural postmodernization and engage creatively widespread sensibilities about the perceived failure of post-World

\footnotetext{
${ }^{3}$ Unless otherwise specified, "modern democracy" refers to European-style social democracy as well as more market-centered liberal democracy. "Modern theory" refers to convergent facets of classical social theory and later theories that followed in their tracks (e.g., Antonio and Kellner 1992a, 1992b).
} 
War II modernization. They also amplify powerful, key tendencies of resurgent neopopulist movements, cultural wars, and racial, ethnic, and religious conflicts. My main focus is on a recurrent 20th-century theoretical tendency, the "total critique of modernity," or a highly pessimistic fusion of one-sided Nietzscheanism and one-sided Weberianism that treats modern theory's hopes about social progress as moribund and portrays profound exhaustion of modern democratic culture and institutions. It has animated theoretical convergences between the radical right and cultural left, and it appears again today in overlapping facets of "radical conservatism" and "strong-program postmodernism." Total critique counters modern theorists' "historicist" and "dialogical" method of "internal critique" and their other core presuppositions. My exploration of the resurgent reactionary tribal alternative will help draw out the role of "social theory" (i.e., a distinct type of normatively oriented discourse anchored in "sociological argumentation") in the problematic relationship of science and partially disenchanted public spheres in plural, democratic cultures. Probing what is at stake in the revived debates over modernity and postmodernity, I address the type of moment that Weber spoke of nearly a century ago-the ending of a historical conjuncture (i.e., the postwar era) when existing sociocultural ideas and practices are challenged.

\section{ENDINGS' DISCOURSES: FIN DE SIÈCLE SOCIAL THEORY}

We stand, I believe, with a clearing ahead of us. The exhaustion of Modernism, the aridity of communist life, the tedium of the unrestrained self, and the meaninglessness of the monolithic political chants, all indicate that a long era is coming to an end. (Daniel Bell) ${ }^{4}$

Modern-democratic theories usually have been anchored in a "positive," "ethical" vision of modern culture and a historicist idea of "progress" that bridges the tension between normative ideals and actual social conditions (Mannheim 1955, pp. 219-29). From the start, modern theorists claimed that emergent sociocultural modernity and its immanent logics of development forge new types of complex cooperation and communicative capacities that advance individual autonomy, social justice, and social participation. These visions have, over time, grown more inclusive and multicultural. Modern theorists argue that sociocultural differentiation and rationalization, regardless of their repressive features, provide vital resources for overcoming traditional constraints, coping with modern pathologies, and creating a more liberated or pacified future (Antonio and

4 The passage is from Bell's 1978 foreword to Cultural Contradictions of Capitalism, published originally in 1976 (for the quote, see Bell [1996, p. xxix]). 
Kellner 1992a, 1992b). Faith in progressive modernization has contributed to the legitimacy of modern societies and politics. Postwar modernization theories replayed this theme and were a core feature of sociocultural legitimation. However, more recent claims about the "end of history" challenge this faith and legitimacy.

The quote at the head of this section illustrates the sense of profound exhaustion found in the endings' discourses that have became all the more pervasive after Bell's prescient critique of cultural postmodernity. In another work, he sounded even more pessimistic: "All hopes have seemingly been betrayed. The Owl of Minerva which once flew at dusk has folded its wings, . . . the direction of History has been lost, and it knows not what to tell us" (1990, p. 43). Opening a now-classic essay, Fredric Jameson (1984b, p. 53) equated postmodernism with "inverted millenarianism," stressing "the end of this or that (the end of ideology, art, or social class; the 'crisis' of Leninism, social democracy, or the welfare state, etc., etc.)." Converging with the culturally conservative Bell, the Marxist Jameson argued that extreme cultural fragmentation disorients people and prevents them from locating themselves in history, grasping its shape, posing normative stances toward it, and altering its directions. These diverse theorists imply an end of the sociocultural conditions and of types of subjectivity that modern theorists, from Marx to Parsons, argued animated social progress. Later 20th-century theories of modernity have debated centrally the possible depletion of the historical resources that earlier modern theorists believed were arising from, guiding, and advancing progressively modernization.

Posed at the moment that Soviet communism was collapsing and Chinese communism was reeling, Francis Fukuyama's "end of history" thesis received widespread public attention and became the prime textual marker of the ending of the postwar era $(1989,1992)$. Fukuyama argued that the revolutions of 1989 opened a new posthistorical era of global neoliberalism, ending futile utopian dreams and grand struggles in their name. He saw progressive-liberal welfarism, New Left politics, and socialism as moribund and capitalism and the liberal state, shorn of their misguided egalitarian and socially engineered postwar excesses, to have triumphed decisively and globally: "There is no apparent or obvious way in which the future will represent a fundamental improvement over our current order" and no "realistic alternatives" to market liberalism (Fukuyama 1992, pp. 51; 1999, p. 33). Left-leaning modern theorists and postmodernists alike attacked Fukuyama's neoconservative celebration of markets and minimalist mass democracy. But they, too, implied that there are "no alternatives."

For example, the postmodernist Zygmunt Bauman spoke exuberantly about postmodernization's ridding us of postwar modernity's "false con- 
sciousness," rigid structuralism, social engineering, and state centeredness. A refugee from Polish communism, he applauded the prospect of a liberal epoch free from the state socialist "alternative." Like Fukuyama, he described a shift to a more unrestricted market capitalism, but, acknowledging an enormous split between affluent consumers and the marginalized poor, he saw this change as something less than an unqualified victory for democracy. However, on a deeper level, he agreed with Fukuyama, declaring an end of the politics of redistribution (although conceding that socioeconomic polarization and panoptical control of the poor were increasing). He embraced ambivalently "living without alternatives" or accepting the radically divided "two nations society," where relief from statism comes at the cost of social justice (Bauman 1992, pp. 93-113, 175-204; 1993, pp. 240-44; see also Offe 1996, pp. vii-x, 4, 36, 54, n. 9, 171-79). Thus, similar views about neoliberal hegemony appear tellingly across opposing types of theory.

Related claims about the "end of left and right" hold that the primary ideological and policy alternatives, which formerly constituted the modern political spectrum and marked the main divisions between postwar ideologies and parties, have been neutralized. Although the various renditions of this view diverge with regard to hopes about the future, most suggest that the major political parties converge and that their self-acclaimed programs for change are gridlocked. For example, the critical theorist Ferenc Feher (1995) argued that the revolutions of 1989 "deconstructed" the left-right polarity, emptying it of meaning. Although contesting Fukuyaman neoliberalism, Feher saw class politics to have been replaced by ambiguous "tribalism." Leading theorist of the European New Right, Alain de Benoist (1995) also declares an "end of the left-right dichotomy," arguing that, in France, the major parties' centrist moves capitulate to neoliberalism and offer no "real" choices. Unable to regulate and control the activities and influence of global firms, markets, and media, he holds, political leaderships now stress routine management of everyday affairs, executed increasingly in similar ways. Benoist's points about the end of left and right have a highly ambiguous tone, sounding like critiques from the left and converging with Feher. The liberal Anthony Giddens (1994a) puts a much more positive spin on the changes, arguing that the exhaustion of left and right opens space for a "third way" or new cultural politics that reframes "radicalism" in a participatory democratic fashion. But Giddens's ideas and his role in Tony Blair's "New Labor" government suggest exactly the type of move to the managerial center asserted by

${ }^{5}$ For opposing views on the viability of left and right, see Habermas (1990), Bobbio (1996, 1998), and Anderson (1998a, 1998b). 
Benoist. ${ }^{6}$ Also speaking of the end of left and right, even the optimistic Ulrich Beck stresses "congestion" or "paralysis"; "Politics is becoming a silent movie, or, more accurately, a sound movie without the soundtrack. People move their lips and pound the keyboards, but nothing comes out!" (Beck 1997, p. 149). These diverse thinkers imply that, even when old postwar party names remain, convergent mass politics no longer provide alternative sociopolitical visions.

\section{AFTER MODERNIZATION}

\section{Neoliberal and Postmodern Ascent: The Withering Social State}

Fresh modern theories arose with the post-World War II era sociopolitical reconstruction, explosive economic growth, and collapse of classical colonialism. The main non-Marxian position portrayed a sociocultural transition to a fully modern pattern of values and organizational structure, which reflected and justified the postwar era's Keynesian capitalism. The leading postwar sociologist, Talcott Parsons, expressed the period's highly optimistic beliefs about "modernization," and his theories bore the imprint of the Pax Americana. He saw the United States as the "lead society" or model for global development; backwardness would be overcome by convergence of communist regimes with the U.S.-led West and the universalization of the West's "evolutionary breakthroughs." Against the New Left and late 1960s ferment, Parsons rejected mounting "ideological pessimism" about modernization having "suddenly come to an end." He held presciently that rationality, sociocultural difference, and community were becoming major areas of conflict, but he insisted that a new, improved modernity was still dawning. Seeing its "culminating' phase" as "a century or more" away, he declared that the idea of "'postmodern' society" was "decidedly premature" (1971, pp. 142-43). He did not doubt modernization's progressive path. ${ }^{7}$ Social democrats expressed even stronger faith in science, planning, and administration as motors of progress than did Parsons. Although debating appropriate levels of redistribution and regulation, leading postwar modern theories stressed the "state's" vital

\footnotetext{
"On Giddens's "third way" and "New Labor," see the Economist (1998) and Boynton (1997).

7 Parsons's System of Modern Societies summarized his views on modernization long after he formulated his quasi-evolutionary "general theory." Although holding that Europe retained backward aristocratic features (resisting full "Americanization") and that modernization would remain uneven and conflictive in the non-Western world, he doubted "that any major part of the world will settle into a clearly nonmodern pattern of society during the next couple of centuries" (1971, p. 137; emphasis in original).
} 
role in coordinating an upgraded, accelerated, and planned process of progressive modernization.

During the mid- and late-1970s crises, however, neoliberals attacked postwar modernization policies and theories. Seeing state interventionism as the cause rather than cure for "market failures," they tried, with substantial success, to dismantle postwar-era "guided capitalism." After the victories of Thatcher, Reagan, and Kohl, the "neoliberal counterrevolution" brought neoclassical economic theory and free market, free trade monetarist policies to the center stage of policy making. The revolutions of 1989, the collapse of Eastern European communism, and the worldwide erosion of socialism raised this neoliberal tide. Emphasis on Hayekian "spontaneous orders" replaced the Keynesian "visible hand." Waging an effective campaign against the Great Society and "wasteful regulation," U.S. neoliberals held that the state's social and regulatory arms constitute the main source of economic inefficiency, the central threat to liberty, and the primary cause of poverty. They contended that economic revival, community empowerment, and individual self-help required drastic reduction of redistribution and regulation. Neoliberalism defeated decisively competing left and right corporatist, industrial-planning models. Fusing the libertarian and cultural right into a neoconservative alliance, neoliberals retained the idea of progress, sans postwar themes of social justice and inclusion. ${ }^{8}$

Postmodernism raised even more basic challenges to postwar modernization, reviving the types of fundamental critiques of modernity posed after World War I. Postmodernists amplified wider disenchantment with science and rationality, but dwelled on the repressive side of the welfare state and labor-centered left, seeing their Enlightenment baggage as the source of festering problems of environmental degradation, sociocultural exclusion, and soulless regimentation and homogenization. Although partly rooted in "New Left" sensibilities and "sixties radicalism" (e.g., Stephens 1998), postmodernism arose in a broader climate of change on the left, shifting from postwar-era emphases on national parties, labororiented leaderships, state-centered reforms, and social planning to local organizations, pluralistic alliances, identity politics, and risk avoidance and from material needs, structure, and class to culture, agency, and discourse. Postmodernists held that the old left obscured plural sites of cultural domination, the marginalization of minorities, and consequent

${ }^{8}$ Neoliberal restructuring has varied across regional and national settings; different models of capitalism persist (e.g., Boyer 1998). On neoliberalism, see e.g., Harrison and Bluestone (1988), Davis (1992), Harrison (1994), Brohman (1996), Gordon (1996), Frankel (1997, pp. 76-89), Greider (1997), Braun (1997), Brenner (1998). On 1970s corporatist alternatives in the United States, see Paretsky (1996). 
problems of "identity," "recognition," "surveillance," and "normalization." They saw modern theories, especially Marxist ones, to be part of the system of control. Treating capitalism more benignly and indirectly, they implied a reliance on market-based institutions and a more affirmative view of mass culture and mass consumption. Overall, however, postmodernists heralded an end of postwar modernization and its exhaustion as a normative project or progressive endpoint to be achieved.

Although too complex and ambiguous a terrain to be accounted for by a single factor, postmodernists and modern theorists alike stress postmodernism's connection to neoliberalism (e.g., see Bell 1996; Jameson 1984; Harvey 1989; Leinberger and Tucker 1991; Smart 1992; Bauman 1992; Kumar 1995; Antonio and Bonanno 1996; Ashley 1997; Castells 1996, 1997, 1998). Both approaches came into prominence in the United States and Europe, between the mid-1970s and mid-1980s, when the postwar political-economic and sociocultural complexes were eroding and changing. Although usually opposing economic rationalism, postmodernists attack the old left as sharply as do the neoliberal critics. Contending that consumption and lifestyle have replaced production and work as the pivotal facets of sociocultural life, postmodernists hold that neoliberalism's highly differentiated niche markets decenter and localize consumption, subvert rigid, conformist, worker-bee selves, and put an end to class politics. They usually applaud the decline of the Protestant ethic and bourgeois, work-centered life. All but the most pessimistic postmodernists see consumer goods, mass media, and market-mediated lifestyles as contested terrains, repositories of difference, and arenas for articulating plural selves. Eschewing Marxian and Frankfurt school critiques, they imply that neoliberal nitchification and commodification reduce cultural constraints, expand options, and liberate desire and the body. Affirming the transition from high Fordism's centralized, standardized mass production and mass consumption and conformist workaday culture to a more diverse, decentered, and culturally tolerant post-Fordism, they shift from the critique of capitalism to cultural criticism and break more sharply from the old left than did New Left critics.

Postmodernists treat the interventionist welfare state as the linchpin of bankrupt postwar modernization and therapeutic repression. They usually reject the idea of publicly planned social progress, arguing that the postwar social state tolerated, justified, and even orchestrated domination and exclusion. For example, Jean-François Lyotard held that Marxism and Keynesianism "program" technocracy and justify the "totalizing" practices of capitalist and socialist "system managers" (1984, pp. 12-13). His hyperradical poststructuralist critique dismissed the democratic facets of postwar society and culture as illusory, yet his extreme pluralist, anticonsensual stance implied an individualism that has affinity for the very liberalism 
it purports to reject (Ferry and Renaut 1990, pp. xvi, 15-19, 64-67). Taking an even a dimmer view of "social engineering," the U.S. postmodernist Charles Jencks described Pruitt-Igoe (a St. Louis public housing project and high-rise ghetto) as the prototypical outcome of postwar modernization; he viewed its demolition as the dawn of postmodernity (1986, pp. 180-81, 371-73). Ranging from Foucauldian broadsides against the therapeutic state to milder critiques of postwar planning and risk management, postmodernist approaches converge with neoliberal arguments that the scaled-down social state will reduce repression, empower communities, and free individuals (see, e.g., Jencks 1986).

Although viewing optimistically the post-postwar era as "second" or "reflexive" modernity, Ulrich Beck (1992a, 1992b, 1997) and Anthony Giddens (1994a) share postmodern sensibilities about the failed left and the superiority of cultural politics. They hold that the postwar left's overly ambitious, state-centered, egalitarian policies justified the era's formulaic knowledge, top-down procedures, and technocracy. Beck's glowing account of a supposed shift from the postwar "authoritarian action state" to today's "negotiation state" presumes unproblematic continuance of postwar welfarism and ignores completely neoliberal erosion, polarization, and counterforces $(1997$, pp. 26, 95, 140). His declarations about the end of class and the "individualization of social inequality" seem very farfetched in the United States (e.g., where about $50 \%$ of African-American and Hispanic children are born into poverty). Except for historical references, capitalism is largely invisible in suç accounts of "reflexive modernity."

Critics charge that postmodernists take "on the color" of neoliberalism and act as if capitalism "does not exist" (e.g., Eagleton 1996, p. 23; Žižek 1997 , p. 46; Rorty 1998 , pp. $35-37,87$ ). Normative views aside, postmodernists and their critics alike betray a substantial loss of confidence in the state, serious erosion of the political mechanisms that were once believed to guide modernization and social progress, and increased hegemony of the economic over the political. These themes cut across the endings' discourses and arguments about the convergence of left and right. Efforts to cope with this perceived weakening of regulatory capacity can lead toward very different types of regimes, but a rising chorus calls for a retum of the political (e.g., Mouffe 1993).

\section{"Cultural Postmodernization": Fractal Culture Rules}

Cultural postmodernization refers to the sociocultural processes and overall pattern of change that have manifested and fostered the ideological 
and policy trends mentioned above. ${ }^{9}$ Diverse thinkers imply that the process is producing the basic sort of change that Weber held would stimulate fundamental theoretical shifts, but they disagree over its form, impact, and periodization. I stress three themes that have been important focal points of debate and crucial contexts for the erosion of postwar modernization theories and for convergent themes addressed by postmodernist and reactionary tribal theory.

The idea of autoreferential culture, one of the most widely debated facets of postmodernization, holds that culture operates according to its own autonomous logic, free from modern theory's formative sociological substrates (e.g., Durkheimian association or Marxian class or value). This view emphasizes a split between the "signifier" and "signified" (i.e., symbolic codes lack shared conceptual and external referents or common meanings and objects) and consequent semiotic determination (e.g., Baudrillard 1983a, 1983b; Jameson 1984, pp. 60-62, 80-88; 1991; Bauman 1992, pp. 149-55; Kumar 1995, pp. 101-48; Eagleton 1996, pp. 14-15, 121-35). Extreme positions treat culture as a totally autonomous "regime of signification" (i.e., signifiers circulate in a purely contingent manner and all "real" factors, alleged as "beneath" or "behind," are "simulated"). They reduce society to an all-encompassing "cultural surface" that is unconstrained by "material" or "structural" factors. Modern theorists and many postmodernists attack this position for its radical culturalism, but they still concede that it expresses a major qualitative or postmodern shift in cultural experience that weakens the social and the ability to represent it. They see postmodern "depthlessness" as a "cultural dominant" or pervasive facet of bounded domains of the mass media, consumer culture, the arts, and certain other major parts of sociocultural life. Modern theorists theorize postmodernism as a "logic" of late capitalism, but they warn that the culture's simulated appearance subverts their own claims about its "depth" determinants (e.g., Jameson 1984, 1991; Bell 1996; Harvey 1989; Eagleton 1996). They reject arguments about total autonomy and total fragmentation, but they still contend that postmodern culture undermines audiences' capacities to grasp, assimilate, apply, or even take seriously their theories or other systematic efforts to analyze or intervene in social life. The difference between extreme and moderate positions may be less than modern theorists wish to admit. Their very heated critiques

${ }^{9}$ Neoliberal theories and postmodernist theories are part of cultural postmodernization. Thus, "causal" connections between them and other facets of the overall process are complex. On postmodernism and postmodernization, see e.g., Harvey (1989), Best and Kellner (1991), Jameson (1991), Bauman (1992), Smart (1992), Dickens and Fontana (1994), Kumar (1995), Ashley (1997), Antonio (1998). 
of the process reveal a fear that Baudrillard is right; that the line between TV and the rest of culture has been elided (1990).

A closely related theme, antiuniversalism, opposes the alleged regimenting, homogenizing force of universal values, concepts, laws, and policies and manifests a deep suspicion or outright denial of cross-group consensus. This particularlist current is amplified by Derridian and Lyotardian mantras about waging "war on totality," celebrating "difference," and embracing "local knowledge." Antiuniversalism runs counter to the "grand narratives" that legitimized modernization and attributed it general significance. From this vantage point, Marx's materialist theory of history, Habermas's reconstructive ethics, and Rawls's deontology all erase cultural difference and justify repression (e.g., Lyotard 1984; Bauman 1992, 1993; Rawls 1971; Habermas 1984, 1987b). The same tendencies are manifested in objections to ideas of general "emancipation" and "difference blind" social rights (e.g., Gutmann 1994; Nicholson 1996). The crucial question is whether this particularism is so strong that it precludes the possibility of divergent groups communicating, reaching uncoerced agreements, and living together cooperatively and peacefully. In matters of race and ethnicity, antiuniversalist views range from support for affirmative action and recognition of minority differences to advocacy of racial separatism or from efforts to preserve local communities and regional dialects to "ethnic cleansing." They sometimes pit preservation of national, communal, or subgroup particularities and identities against wider, more impersonal, or universal forms of solidarity, citizenship, or rights. Such positions imply that "ethnos" is or should be the ascendent factor in sociopolitical solidarities. Enlightenment universalism is equated with cultural homogenization, the destruction of community, and the evaporation of cultural autonomy. However, debates rage over whether this antiuniversalism counters postwar excesses and favors cultural liberation or fosters insularity, internecine conflict, and repression (e.g., Schlesinger 1992; Benhabib 1996; Barber 1996).

Stressing the centrality of "new social movements" (NSMs), diverse thinkers argue that cultural politics are ascendent over class or the redistributional politics of welfare-state liberalism, social democracy, and Marxism and have shifted politically oriented collective action and social criticism from a primarily modern, material, universal plane to a postmodern, discursive, local one. The environmental movement posed basic challenges to modernization, shifting to postmaterialist ideals and opening wider, more-inclusive public dialogue about the risks, costs, and blindspots of top-down applications of science and planning and of unsustainable, harmful development policies. Environmentalism decouples modernization from sociocultural progress and stresses local action. But the politics of "recognition" or "identity" have more globally widespread, diverse 
forms and are prime carriers of the culturalist and antiuniversalist tendencies mentioned above. Stressing disparaged marginalized strata (e.g., racial-ethnic minorities, lesbians and gays, women), they address types of cultural exclusion and damage, exacerbated or ignored by postwar politics. Intense battles rage about the status of NSMs, especially over the question of whether they reconstitute the left in a new pluralist alliance politics based on a nascent ideal of "heterotopian" democracy or are an ambiguous, mainly professional middle-class politics that make some progressive gains but add to sociopolitical fragmentation and leave the poorest and weakest people to languish.$^{10}$ Putting aside this debate, advocates and critics agree that NSMs shift the focus of politics and theory from class and capitalism to culture and the state. NSMs are part of a global wave of subgroup, regional, and nationalist struggles for cultural identity and autonomy.

\section{Strong-Program Postmodernism: Total Critique of Modernity}

Cultural postmodernization has divergent impacts and generates diverse theoretical responses. My focus, below, is on "strong-program postmodernism," which amplifies the extreme versions of the three dimensions of postmodernization discussed above. Neutralizing the sociocultural presuppositions of modern theory, this view poses a "total critique of modernity." In general, postmodernists see theory and science as perspectivist "narratives" arising from, justifying, and reproducing hegemonic relations and identities of specific sociocultural locations. But strong-program postmodernism abandons all "truth" claims, viewing social theory and science exclusively as narratives, rejecting references to "realities" external to the theoretical text, and dismissing "objective" inquiry about the "validity"

\footnotetext{
${ }^{10}$ Enthusiastic supporters see NSMs as entirely new forms of symbolic expression and collective action, instituting fresh types of cultural goals and radical democratic dialogues (beyond mass political parties and administrative systems). They claim that NSMs reframe the old left in a more discursive, critical, inclusive, and participatory fashion, breaking fundamentally with "interest-group politics" and constituting a new overall sociopolitical steering mechanism (e.g., Giddens 1991, 1992, 1994a, 1994b; Beck 1992a, 1992b, 1994, 1996, 1997; Beck, Giddens, and Lash 1994; Gutmann 1994; Mellucci 1996). By contrast, critics argue that NSMs are fractious interest-group politics that split the left and ignore economic injustice (e.g., Wood 1986, 1995; Gitlin 1995; Eagleton 1996; Žižek 1997). Harsher critics see NSM leaderships and core members as a "new class" of bureaucratically entrenched, "politically correct," pseudo-left professionals (e.g., Piccone 1990-91; Lasch 1995). For contrasting views about the shift to cultural politics, see Judith Butler (1998), and Nancy Fraser (1998, 1995, 1997).
} 
of theories or how well they represent "reality."1 In this view, claims that theory can grasp obdurate external realities are foundationalist distortions that obscure culture's "constructed" nature. Arguing that perspectives from divergent locations are incommensurable and impervious to intersubjective consensus, it neutralizes the keystone of reflexive versions of modern and postmodern social theory-the "communication model" or the presupposition that people, from different social locations can, at least in principle, reach uncoerced understandings about problems, theories, methods, concepts, empirical claims, and policies by employing systematic methods of knowledge production and adhering to norms of free inquiry and open discussion. The communication model does not substitute homogeneity for multifarious differences but implies that communicative "give and take" favors appreciation of difference and the peaceful resolution of conflicts, which, reducing reliance on raw power and nurturing mutual recognition, make possible uncoerced cooperation. ${ }^{12}$

Usually entwined with radical identity politics, the "politicized" variant of strong-program postmodernism contends that the cognitive and normative interests of hegemonic sociocultural relations are inscribed so indelibly in modern theory and science that their empirical, interpretive, and analytical standards of judgment are totally politicized and distorted. ${ }^{13}$ Suspending "epistemological privilege," the politicized strong pro-

1 Two major qualifications are in order. First, the strong program is sometimes expressed as an overall theory, but appears more often as a theme or declaration in mixed versions of postmodernist theory. Second, reflexive postmodernism, or the "weak program," converges with reflexive types of modern theory, manifesting the Enlightenment's critical side and opposing its Cartesian tendencies (i.e., disembodied ideas of objectivity and representation that ignore sociocultural location and that exaggerate claims about neutral, total, certain representation). Reflexive postmodernism acknowledges power-knowledge, simulation, and cultural difference and criticizes unreflexive modern theories accordingly. By contrast to the strong program, however, it does not hold that postmodernization requires that modern epistemology and communicative ideals be dumped. Addressing critically technocratic, scientistic, and antidemocratic aspects of postwar modernization, refiexive postmodernism qualifies, specifies, and historicizes theory and science. Thus, it continues Enlightenment internal criticism and scales down imperious Reason, but it does not embrace irrationalism (see Antonio 1998).

${ }^{12}$ Reflexive social theorists understand that the ideal of uncoerced communication is very often violated in practice but see its fatalistic rejection to enthrone manipulation, coercion, and irrationality. See e.g., Kloppenberg (1986), Habermas (1984, 1987b) Dewey ([1925] 1988a, pp. 132-90; [1938] 1986, pp. 48-122), Antonio and Kellner (1992a), Antonio (1991, 1998).

${ }^{13}$ Strong-program versions of queer theory or feminist theory claim that the intersubjective standards that govern inquiry are so one-sidedly heterosexual, phallocentric, or masculinist that they cannot be disentangled from the practices of power or produce valid knowledge for queer or female subjects (Seidman 1991a, 1991b, 1992; Richardson 1991). By contrast, reflexive-postmodernist feminists or queer theorists also aim at 
gram rejects judging and ranking knowledge according to its purported capacity to represent reality. Rather, it holds that treating theory and science as self-interested "texts" or "stories" puts discredited minorities' marginalized ideas, values, and ways of life on the same plane as those of hegemonic strata and prevents them from being disparaged by epistemological slighting. Although retaining taints of Marxian "standpoint theory," this view treats sociocultural locations and identities as alldetermining forces and reduces knowledge to hermetically sealed cellular standpoints. Consequent subversion of the communication model forbids the cross-group consensus and cooperation needed to sustain this position's usual espoused multicultural ideals.

A second or "depoliticized" version of the strong program suggests a more radical relativism and profound disintegration of modern theory's cultural bases. At the height of the postwar era, Henri Lefebvre held-explaining his break from Marxist historicism and progressivism-that new forms of media and information production reduce "social reality" to a "system of signs and significations" and that it "loses all its solidity, its substantiality and its frames of reference; it begins to crumble-or rather, to evaporate." Hence arises, he warned, a "world of boredom" and "nostalgia," ruled by the "aleatory" or complete chance ([1962] 1995, pp. 204, 222-23). Radicalizing this view in the 1970s and 1980s, Jean Baudrillard held that all-pervasive "simulation" melts all that is solid into a flat, fluid cultural surface of incommensurable, fragmented, transitory, "floating signifiers." Arguing that all distance from the text is lost and that cultural representations are self-referential, he precludes social knowledge and favors purely aesthetic responses (e.g., Baudrillard 1983a, $1983 b$ ). In his view, modern theory's core epistemological and normative distinctions (e.g., ideal-real, true-false, good-bad, base-superstructure, culture-society) have evaporated. Thus, "progressive" facets of history are not distinguishable from their opposites. All dissolves into pure contingency, ending communication, meaning, and sociality and foreclosing the basic democratic presupposition that people are capable of absorbing information, digesting it critically, and employing it reasonably in citizenship, popular sovereignty, and social cooperation. In this version of

major transformations of mainstream views of gender and sexuality and criticize modern theories accordingly, but their ideas of social knowledge parallel reflexive modern theorists. Their qualified idea of "objectivity" takes account of its situated, plural nature, yet averts standpoint theory's radical relativism. They believe that social science's effectiveness increases with the recognition that its "truths" are plural, partial, imperfect, contingent, and transitory and that engagements between diverse communities, beliefs, and ideas make social knowledge richer, wider, and stronger. They see social knowledge as much more than a self-enclosed, in-group narrative; it can and should extend far beyond the theorist's circumscribed location (e.g., Haraway 1988; Fraser 1995; West 1989, 1993; Seidman 1996a, 1996b). 
the strong program, the "end of politics" goes hand in hand with the "end of history." Radicalizing the idea of cultural exhaustion and the total critique of modernity, it opens the way for postliberal critiques and "solutions." As I will explain below, reactionary tribalist theorists converge with and appropriate from the politicized strong program, posing an extreme version of identity politics and standpoint theory in order to overcome the depoliticized strong program's nihilism, which they hold suffuses cultural life under neoliberal rule.

\section{AFTER POSTMODERNISM: REACTIONARY TRIBALISM}

Instead of "Demos," Society, Covenant-Ethnos, Tribe, Race! (Aural Kolnai 1938, p. 431)

\section{Retribalization: Against the Market and the Neoliberal State}

Retribalization refers to a neopopulist resurgence of group identities anchored in ethnic community. ${ }^{14}$ For example, a right-wing populist states: "The end of the Cold War has given us the New World Order but also made manifest the tendency of the modern world toward tribalism. The tendency runs deep. Man forms tribes because he knows what he is by contrast with what he is not, and because a single worldwide society is far too vast for feelings of participation and loyalty. When he finds himself in a society that lacks the cohesion to be a community man remains a political animal and finds means to create some form of polis" (Kalb 1998, pp. 1-2). Globalization, deregulation, and the erosion of the Cold War geopolitical system helped fuel new aspirations and struggles for local autonomy and assertions of collective identity against freely moving capital, goods, jobs, people, and images. New tribalism bears the imprint of and helps drive postmodernization, especially its centrifugal forms of cultural fragmentation, antiuniversalism, and identity politics. It also raises important questions about the role and vitality of the democratic state,

${ }^{14}$ I employ "ethnic" to designate diverse types of "tribes," based on linguistic, religious, racial, and other cultural differences. Examples of right-wing neopopulism are the French National Front, the Italian Northern League, the Belgian Vlaams Blok, the German Republican Party, the British National Party, New Zealand First, the Indian Bharatiya Janata Party, and the U.S. League of the South. On retribalization see, Boyte and Riessman (1986), Bauman (1992, pp. 136-37, 196-200), Betz (1994), Piccone (1995), Maffesoli (1996), Barber (1996), Betz and Immerfall (1998), Hughey (1998). On ethnic identity in a hybrid age, see Appiah and Guttman (1996) and Walzer (1997). 
especially its capacity to cope with and preserve cultural difference. ${ }^{15}$ The new tribes often charge that postwar social democracies and today's neoliberal states do not recognize or support adequately their group particularities and that liberal universalism "homogenizes" difference. Tribalism suffuses the NSMs, which stress open dialogue and active citizenship and embrace multicultural civil society and representative democracy, but it is also pervasive in reactionary types of xenophobia, racism, violence, and, genocide (e.g., Bosnia, Rwanda, Afghanistan, Northern Ireland, the U.S. Aryan Brotherhood, and Identity Christianity).

Even Fukuyama warned that prosaic economism and cultural relativism make neoliberal regimes vulnerable to attack from the far right (1992, pp. xxii-xxiii, 181-244, 300-39). Discussing Fukuyama, Allan Bloom held that if "an alternative is sought there is nowhere else to seek it. I would suggest that fascism has a future, if not the future" $(1989$, p. 21). When belief in modernization was strong and the memory of fascism was vivid, protofascism was usually seen as an irrational reflex or symptom of a collective character disorder. However, New Right critiques of the culturally fragmenting, depoliticizing impacts of neoliberalism and postmodernization are sophisticated and innovative and deserve serious consideration. In light of today's escalating forms of bloody retribalization (e.g., Kosovo and East Timor) and deepening economic and cultural crises in important regions (e.g., Russia), claims that such radical right views may become more widely popular do not seem so far-fetched. Roger Eatwell attaches special significance to resurgent radical conservative theories and European New Right theories. He states that

the most promising form of neofascist radicalism in terms of burying the past is the attempt to rehabilitate the German conservative revolutionaries, like Ernst Jünger . . . and key intellectuals who supported fascism, like Carl Schmitt and Martin Heidegger. ... The French New Right, in particular its key theorist Alain de Benoist, has turned to the conservative revolutionaries and Schmitt for much of its inspiration, particularly to their ideas on the importance of re-creating national identity. (Eatwell 1997, p. 360)

\footnotetext{
${ }^{15}$ For example, see debates over Habermas's and Rawls's left-liberal universalism (e.g., Habermas 1984, 1987b, 1993, 1996, 1998; Rawls 1971, 1996; Benhabib and Dallmayr 1990; Strong 1992), communitarian critiques of liberalism and universalism (e.g., Sandel 1998, 1996; Bellah et al. 1986; MacIntyre 1988; Selznick 1992; Etzioni 1995; Bell 1995; Guttman 1994; Walzer 1997; Mulhall and Swift 1992, and Philosophy and Social Criticism 14 [nos. 3, 4]), and discussions of identity politics (e.g., Schlesinger 1992; Giddens 1994a; Gitlin 1995; Hobsbawn 1996; Rorty 1998; and Benhabib 1996). These approaches all focus ultimately on the problematic nature of political community and power after the blurring of boundaries by capital mobility, global mass culture, transnational entities (e.g., NAFTA and the European Union), and immigration.
} 
Although still objectionable in "polite company," Eatwell warns, neofascist theories offer a countervision that could become much more widely embraced, especially in an economic downturn.

\section{European New Right: The Return of the Political}

The European New Right claims to fuse the radical antiliberal facets of left and right into a new, vibrant "Third Way." For example, New Right opposition to African, Middle Eastern, or Asian immigration stresses the evils of capitalist globalization, resistance to cultural homogenization, and defense of cultural identity and difference. Their pleas for "ethnopluralism" transmute plans to repatriate immigrants into a left-sounding antiimperialist strategy championing the autonomy of all cultural groups and their right to exert sovereignty in their living space. Claiming to counter "antiwhite racism," they argue that multiculturalism serves global capitalism's merciless leveling and that only exclusionary monoculture nurtures genuine cultural diversity. They also pose "green" agendas to protect their homelands from overpopulation, overdevelopment, and other ravages of the neoliberal "New World Order" and latest and most exploitative phase of Enlightenment. ${ }^{16}$ They often deploy New Age spiritualism, inscribed in pagan or early Christian symbols, to foster reenchantment and remythologization. Following the New Left and today's postmodernist cultural left, the New Right stress the ascendancy of cultural politics. Reshaping radical conservatism for postmodern times, they employ cultural studies' favorite forerunner theorist, Antonio Gramsci, an icon of their fusion of left and right and use his idea of "cultural hegemony" against the liberal left (e.g., Sunic 1990, pp. 14, 29-41).

Eatwell holds that the New Right's "ideological core" is little changed from first-generation radical conservatism's "holistic-national radical Third Way" (1997, p. 361; emphasis in original). Recently resurrected and appropriated by the New Right, the original Weimar-era approaches bear the imprint of radical tribalism. ${ }^{17}$ Following Nietzschean antisociology, they charged that modern theorists elevate "decadent" values into guiding ideals and that their universalist grand narratives of modernization produce pernicious leveling of cultural particularity. They were influenced strongly by Nietzsche's antiliberalism and total critique of modernity, but

${ }^{16}$ Lambasting "Americo-cosmopolitanism," a British nationalist declares that only tribalism can save "our peoples and cultures and ethnic identities from homogenisation into bland burger-filling sludge by the global capitalist mincing-machine into which they are inexorably fed" (Charnot 1998, pp. 3).

"Aurel Kolnai's (1938) classic overview of fascist and protofascist theories was helpful in this section. Also, see Herf (1986), Lepenies (1988, pp. 334-49), Sunic (1990), Zimmerman (1990), Aschheim (1992), Dahl (1996,1999), Woods (1996), and Pels (1998). 
they reformulated his ideas into nationalist visions that he rejected. Inverting the idea of a progressive shift from homogenous tribes, rooted in "ethnos," to plural modern societies, based on "demos," radical conservatives held that modern theory affirms normatively an actual descent from animate cultural diversity to souless universal technocracy. They contended that modern democracy's melding of diverse ethnic groups into a mass "society" destroys their distinctive cultural identities. ${ }^{18}$ In their view, it dissolves cultural community into atomized, selfish, impersonal economic relations. Radical conservatives decried liberal-left efforts to impose formal and substantive equality, holding that allegedly suppressed natural inequalities ought to be cultivated and employed within the ranks of the domestic sociopolitical order. Overall, they envisioned an "organic" hierarchy of corporate groups and loyal subjects, regimented in a pseudocommunal way under natural leaderships. ${ }^{19}$

Heidegger held that "Europe lies in a pincers between Russia and America, which are metaphysically the same"; that is, their economism and instrumentalism causes a "darkening of the world" or "always-the-sameness" (1961, pp. 36-39). In his view, the hegemonic modern emphasis on technical rationality turns people into a timid, powerless, mediocre, nihilistic mass or a totally homogenized technological civilization devoid of cultural creativity. Heidegger and other radical conservatives contended that capitalism and socialism are both rooted in the West's characteristic universalistic rationalism. Still manifesting this exhausted cultural complex, they held, left-wing "revolution" cannot forge a genuinely new culture. They still considered communism an especially dangerous and formidable enemy, fearing that its antiliberal communalism, statism, and internationalism could forge the solidarity and discipline that are lacking in liberal democracy. They believed that the left could grab political power, but that would merely harden the grip of bankrupt Western civilization. They thought that communism's instrumentalist, egalitarian rationalization would suppress all opposition and be the bane of all culture. Radical conservatives hoped that radical segments of the cultural left, sharing

${ }^{18}$ Ethnic differences were often seen to be biologically based. However, sophisticated theorists, such as Carl Schmitt, provided essentialist cultural justification for exclusionary ethnic policies. For example, Schmitt argued that Arab immigrants to France, unwilling to give up Moslem religious law, cannot be integrated into French culture and that Australian efforts to curb Asian immigration manifest an awareness of obdurate cultural differences that preclude assimilation into a European order ([1926] 1988 , pp. 8-17, 90-91, nn. 26, 30). The New Right employs this view widely today, along with biological arguments.

${ }^{19}$ Kolnai, held that they embraced "the ideal of 'organic' social order, of the 'natural' rule of aristocratic minorities"; "It is the old issue again Herrschaft versus Society: feudal loyalties versus reason and contract" (1938, pp. 644, 646). 
their virulent hatred of liberal institutions and belief that bourgeois culture was totally spent, would join a "revolution from the right" aimed at demolishing sociocultural modernity and putting modern technology in the service a truly new cultural complex. Radical conservatives saw the political spectrum as a sharply bowed horseshoe; the extreme left occupies an opposite, but proximate end of the continuum. They hoped that left radicals would give up on their failed revolution and make the short jump to the extreme right, closing the "ends of a horseshoe" and encircling the common liberal enemy (Kolnai 1938, pp. 113, 235).

Carl Schmitt's political thought is discussed, today, by diverse thinkers, but it is especially important for New Right theorists, who cite and employ it widely in their positions. ${ }^{20}$ Schmitt held that the "political" is an autonomous domain that has primacy over other sociocultural realms. He argued that the "friend and enemy" dichotomy, the "strongest and most intense" social distinction, is the essence of the political. In his view, politics' vibrancy rises with the level of collective enmity toward the enemy and the more it is the decisive factor in group identity. He held that "the high points of politics" occur when enemies are recognized with "concrete clarity" as "other" or "different and alien." His theory had a fateful affinity for Nazi anti-Semitism. Expressing an extreme particularism, similar to today's politicized version of strong-program postmodernism, he saw the globe as a "pluriverse" of incommensurable, mutually impenetrable cultures and the friend-enemy polarity as the wellspring of their distinct identities. However, Schmitt warned that universal economism and egalitarianism are leveling these vital differences and that nationalist politicization is needed to resist and stem the process ([1932] 1996, pp. 25-27, 53, 67-68).

Schmitt charged that modern theory's core concept of "society," by treating the political as merely one of a plurality of associations and, thus, denying its primacy, gives free rein to fragmentation, atomism, and economism. ${ }^{21}$ Precluding a clear friend-enemy distinction, he held, modern

${ }^{20}$ Like Heidegger, Schmitt's role in the Nazi movement make him a very controversial theorist. Schmitt's Catholic roots and critique of political romanticism distinguish him from more Nietzschean radical conservatives (e.g., Schmitt [1925] 1986; Sunic 1990, pp. 43-50, 67-80). Although a crucial figure for the New Right, his ideas are sometimes employed in democratic discourses by left liberals and moderate conservatives (e.g., see Mouffe 1993; Kalyvas 1999; Turner 1996). For opposing views of Schmitt's thought, see Bendersky (1987) and Wolin (1992). Scanning Telos from the late 1980s to the present is informative about Schmitt's importance for the new fusions of right and left.

${ }^{21}$ Schmitt claimed that the "friend-enemy grouping" forges "a decisive entity which transcends mere societal-associational groupings" (1996, p. 45; emphasis added). He argued that there is no need for the abstract idea of society, when the "essence" of the political is grasped correctly and rightfully empowered as the prime manifestation of 
democracy's cultural diversity, pluralism, and multiparty politics generate all-pervasive conflicts of interest and heartless compromises, which depoliticize the nation. By contrast to Weber's liberal view of domestic politics as peaceful debate, struggle, and compromise over conflictive values and interests, Schmitt held that the state should unify a people against enemy cultures. Liberal rejections of this genuine politics as repressive, he argued, justify the subordination of political community to markets and "possessive individualism." He wanted to see an end of politics in the liberal left sense of discursively mediated competition and voluntary cooperation between diverse groups, persons, parties, interests, policies, and values (Schmitt 1996, pp. 71-72; 1988, pp. 48-50). Schmitt saw the modern democratic state's internal bickering and brokering of interests as a mere shell of the political. Moreover, he held that its universalist idea of "humanity" favors "economic imperialism" and cultural homogeneity abroad as well as at home. Although sometimes sounding like a later Frankfurt school critic of "totally administered society," Schmitt called for a total state to restore the political's rightful primacy over capitalist society, combat enemies, and curb subjects' evil ways (1996, pp. $45,54-58,62,68-71)$.

The recently revived European New Right repeats many of the first generation's positions, but it refashions the old ideas to fit culturally postmodernized settings and to divorce its agenda from the former fascist regimes and from the Holocaust. The leading theorist of the French New Right, Alain de Benoist, provides an exemplary version of "postmodernism 'of the right," trumpeting radical conservatism to the Derridian-sounding tune of the "right to difference," mixing Schmitt with Gramsci, and blurring left and right (Taguieff $1993-94 a$, p. 103). ${ }^{22}$ Like others of the New Right, however, he rejects multiculturalism and takes a Schmittian view of European identities. He says he wants to protect continental ethnopluralism and to preserve the local cultures of Europe's diverse ethnic and linguistic groups, empowering them politically as autonomous regional entities in a larger imperial unit. In his view, only federated "organic communities" can resist global neoliberalism and its seductive U.S.spawned consumerism and mass media. Following Schmitt, Benoist advocates nurturing local homogeneity to fight capitalism's universal ho-

a distinctive cultural community. The last section of Schmitt's (1996, pp. 69-79) essay provides a lucid example of radical conservative criticism of modern theory, especially liberal economism and pluralism.

${ }^{22}$ By contrast to Schmitt, Benoist calls for a Nietzschean break with Western culture's Christian roots. Widely influential in European New Right circles, his work is now often published in the U.S. journal Telos. On Benoist's place in the New Right, see Sunic (1990), Taguieff (1993-94a,1993-94b) and Telos, nos. 98/99. On radical conservatism and the New Right, see Dahl (1999). 
mogenization, but he applauds active civic life, public discussion, direct democracy, and North American communitarism. His scathing broadsides against liberal individualism have a clear affinity for the Sandel-BellahTaylor-Etzioni-MacIntyre critiques of fictional monads that are supposedly able to choose, act, and frame identity independent of communal ties ("unencumbered selves"). His incisive attacks on neoliberal globalization and Hayekian economics are quite scholarly and sophisticated, converging with work by the most able left liberal theorists. Rejecting Le Pen's Front National and openly racist nationalism, he claims to embrace NSM "politics of recognition." Believing the nation-state and left politics to be exhausted, Benoist contends that new assertions of collective identity and "proliferation of networks and multiplication of 'tribes"" offer alternatives to liberal left leveling (1993-94b, pp. 195, 203-4; 1993-94a, pp. 95-97; 1995, 1997, 1996a, 1996b, 1998b, 1998c,, 1999).

Benoist's direction is visible in his friendly references to Schmitt and other radical conservatives and in his equation of modern democracy with extreme domination and exhaustion (i.e., total atomization, instrumentalization, and homogenization). Seeing capitalist globalization as the cause of today's Third World diaspora, he holds that receiving states, countries of origin, and transplanted people themselves would all benefit from the repatriation of immigrants. He claims that such a move is the only way to preserve difference and foster a heterotopia of autonomous cultures or Schmittian pluriverse; only homogenous ethnically unified communities are capable of sustaining the type of collective identities needed to resist neoliberalism's grim reaper. Like Schmitt, Benoist stresses incommensurable culture, rather than biological difference. He rejects traditional racism and espouses cultural relativism and tolerance, but he argues that cultural differences cannot be mediated communicatively or regulated by common norms. ${ }^{23}$ His self-described "postmodern" move is supposed to counter the West's hegemonic rationalism and cultural imperialism, especially the allegedly corrosive force of its universal human rights and abstract notions of equality (which he argues serve liberal economism and homogenization). He treats democratic universalism and egalitarianism as protototalitarian tendencies, and he suggests that Stalinism and Nazism are rooted in liberal democratic culture's evaporation of particularity and that they provide a staging point for an organicist

${ }^{23}$ Taguieff (1993-94a, p. 108) states that Benoist's "thesis of the radical pluralism of values implies a polylogism prohibiting dialogical communication and an absolute cultural relativism (which links the inability to communicate with the incompatibility of world views) and is compatible only with the affirmation of relative inequalities. Differentialist racism contests the 'racism' of any projection of differences or inequalities on to a single or universal scale of values." For a critique of this interpretation, see Benoist (1999, pp. 44-48). 
inversion of modern democracy. Benoist's convergence with postmodernism's politicized strong program is transparent, except that following more consistently the logic of radical perspectivism's break with the communication model, he argues that cultural diversity can never be preserved in a multicultural society (Benoist 1993-94a, 1993-94b, 1995; Taguieff 1993-94a; Sunic 1990, pp. 125-51).

Benoist claims to champion the "direct democracy" of the ancient Greek polis, but, like earlier radical conservatives, he leaves vague the actual mechanisms of political rule. He does imply, however, that they would invert liberal democracy. Praising the Greek polis for averting liberal fragmentation and paralysis and, thus, being "a community of citizens," Benoist sees "ancient democracy" as "genuine democracy." He attributes its cultural and political integration to the convergence of "demos and ethnos"; that is, citizenship was based on "common ancestry" or the "reverse" of liberal orders where equal rights derive from "the natural equality of all." He is aware that citizens of "ancient democracy" were usually a hereditary status order of landed and militarized propertyholders that relied on ruthless extraction from unfree slave and serf strata and that did not extend equal rights to women. Seeing such dominance and subordination as a natural facet of organic particularity, he asserts that "a certain hierarchical structure" does not diminish the democratic status of such regimes. His idea of ancient "liberty" inverts today's liberal democratic usages of the term. Rather than "emancipation from the collectivity," he argues, ancient liberty affirmed the individual's bond to the community and stressed "inheritance" and "adherence." Accordingly, he held that the "'liberty' of an individual-without heritage, i.e., of a deracinated individual, was completely devoid of any meaning." He also states casually that "slaves were excluded from voting not because they were slaves, but because they were not 'citizens' [i.e., not members of one of the polis's constituent phratries or clans]." In his view, the most vital facet of the polis was its exclusion of outsiders. Conversely, today's hegemonic principles of universal citizenship and human equality preclude his preferred "aristodemocracy" (Benoist 1991). Benoist praised ancient imperial regimes for similar reasons as the polis; they recognized individuals only through their membership in legally empowered corporate groupings or status orders (religions, ethnic groups, communities, and nations). By contrast to the modern nation-state's principle of voluntary association and countervailing power of individual rights, ancient groups were compulsory and had sweeping power over their flocks. For today, Benoist advises, "Imperial principle above, direct democracy below" (Benoist 1993-94a, p. 97). His hoped-for federated European monocultures, where political rights would be tied to ethnos, would empower compulsory groupings, forging communitarianism with an iron glove (Walzer 1997, pp. 14-19). 
The undemocratic features of the premodern polis, the empire, and the feudal state disappear in Benoist's rendering. Ignoring pervasive force and dependency, he praises their "democratic" facets, "spiritual character," solidarity, and integration of the "one and the many" (all emanating from the centrality of "ethnos" and participation limited by status-group membership) (Benoist 1993-94b). He redefine's "direct democracy" as hicrarchical monoculture, which overcomes today's normative emphases on universal citizenship, equal participation, and individual freedom. Posed as a revolutionary "alternative" to mass democracy and liberal institutions, his position, like earlier radical conservative arguments for "organic democracy," points toward protofascist pseudocommunity rather than selfgoverning Gemeinschaft. This direction is manifested in his unproblematical description of the Weimar radical conservative Ernst Jünger's "democracy of the state," or hierarchical order, based on "Prussian principles of command," where "liberty and obedience are one"(Benoist 1998a, 1998b). ${ }^{24}$ Equating modern democracy with spiritless mediocrity, decadence, and deracination, Benoist postures when he expresses appreciative views of North American communitarians, who he must know aim to enliven the very types of representative democracy and liberal institutions that he despises. Claiming that everyone pretends to support democracy today, Benoist employs the term for his own purposes (1991, p. 26). His effort to locate himself as an "organic communitarian" who embraces "community" and "difference" manifests the postmodern split of signifier and signified (Benoist 1993-94a).

Pitting "community" and "ethnos" against "society" and "demos," radical conservatives break with modern theory or the sociological presuppositions of modern democracy. They see the "universe of the particular," or self-enclosed collective identities, as the only bulwark against homogenization. Against universalism and human rights, they hold that divergent cultures cannot reach shared understandings or be judged by common standards. Their radical perspectivism parallels the essentialist standpoint philosophies of postmodernism's politicized strong program. However, they propose an exclusionary monoculture that follows consistently from their break with the communication model. Their inherently conflictive view of intergroup relations treat power-knowledge and dominancesubordination as all-pervasive defining forces among the tribes. Most important, they transform the ideals of freedom and autonomy from qualities

${ }^{24}$ Distinguishing the "total state" (i.e., the "moribund, inflexible, mechanised, petrified" "totalitarian state") from the "democracy of the state," where "the leader" represents the community in a "supple, living, and organic" manner, Benoist is not troubled by the fact that these two regimes might be hard to separate or that both would be viewed as authoritarian by today's democratic standards (1998b, pp. 7-8). Rather, he prefers the risks of a total state to modern democracy. 
of individual citizens to attributes of a unitary, collective political subject. The radical conservative strategy of strengthening the political center and empowering groups over individuals is posed, today, as therapy for the homelessness, fragmentation, and unconstrained, nihilistic individualism that allegedly inhere in the neoliberal political economic regime and in cultural postmodernization. However, the total state lurks behind their critique.

\section{U.S. Paleoconservatism: Straussian Minimalism}

By contrast to European "nation-states," the United States has been primarily an "immigrant state." The lack of a "permanent" ethnic majority and territorially based ethnic groups favor "imagined community" over that based on habitus. The emphasis on individual citizenship and tendency to minimize recognition of group rights favors hybridization and weaker ethnos (Walzer 1997, pp. 30-35). Consumerism and media culture add to the individualizing and massifying tendencies. In this light, the United States offers little cultural basis for European-style New Right strategies (i.e., what "organic communities" exist to be saved?). However, the United States has its own version of reactionary tribalism, appearing dramatically in recent years (e.g., Turner Diaries, militias, the Oklahoma City bombing, the Freemen, abortion clinic terrorism, and the Christian identity movement; see Bennett 1995; Coppola 1996; Lee 1997). The radical right protests multiculturalist criminalization of whites (i.e., as oppressors of colonial and indigenous people of color) and forfeiture of the nation's white Christian roots. Decrying U.S. nationality as mere "passport identity" or mere "citizenship," they argue that the hybridizing or washing away of ethnos threatens the survival of white Americans, disempowering them in ongoing culture wars with resurgent minorities. In Schmittian fashion, they call for the construction of "white identity" to oppose ethnic enemies and to "take back the nation." Although often disclaiming outright racism, they exploit fears about the intense U.S. racial split, minority population growth, and non-European immigration. Reactionary tribalism is also fanned by growing tensions over the uneasy neoconservative alliance between "cultural conservatives" on the religious right, and "economic conservatives" or libertarians and neoliberals. The appearance of "paleoconservativism" suggests a nascent political realignment and "new" vision on the U.S. right that has affinity for and ties to European New Right politics. Paleoconservatives attack neoconservatives for surrendering U.S. sovereignty to the New World Order (e.g., the United Nations, 
the International Monetary Fund, NAFTA) and capitulating to neoliberalism, consumer culture, liberal individualism, and multiculturalism. ${ }^{25}$

Well known to postwar conservatives and a sophisticated forerunner of paleoconservativism, Leo Strauss posed fundamental challenges to modern theory. Straussian thought has roots in European radical conservatism and affinity for key New Right tendencies, but its ambiguities preclude it from being located definitively in these camps. ${ }^{26}$ Straussian theory helped inspire the neoconservative movement, but, in the current shifting and increasingly tribalized political context, it offers a theoretical basis for a sharper antiliberal turn. Strauss fled Hitler's Germany and was mentor to many Cold War-era political theorists at the University of Chicago. Against the postwar high tide of Parsonsian modernization theory and liberal positivism, he urged a return to the philosophical "classics" and the Hellenistic and Judeo-Christian roots of Western culture. His ideas had formative impact on many leading neoconservatives, including Fukuyama and Bloom, who articulated the "cultural issue" on the right. After modernization theory and progressive liberalism crashed and the "Reagan revolution" dawned, Straussians played a central role in the neoconservative cultural war against the moribund Johnsonian Great Society and against more recent postmodernism, multiculturalism, Clintonism, and other trends they see as undermining American civic morality. ${ }^{2 i}$

A sharp critic of "mass society," Strauss anticipated later arguments by Daniel Bell and right-leaning communitarians about a major cultural crisis manifested in the 1960s counterculture and New Left and, later, suffused throughout consumer culture-the unrestrained self that escapes into "art" and "does not defer to anything higher" (Strauss [1968] 1995,

${ }^{25}$ On paleoconservatism, see Woltermann (1993), Francis (1993), Buchanan (1998), Gottfried (1990, 1993, 1994, 1995, 1996); on the split on the American Right, see Commentary 107 (February 1997).

${ }^{26}$ Straussians do not always pose consistently antiliberal positions, and sometimes support global importation of liberal democracy and human rights. Paul Gottfried claims that some Straussians even became McGovern liberals (1993, pp. 156-57). I do not suggest a political consensus among Straussians. Strauss provided a sharp cultural critique of mass culture that has appeal beyond hardline cultural conservatives.

${ }^{27}$ For example, Robert Bork, William Bennett, Irving Kristol, William Kristol, Clarence Thomas, Casper Weinberger, and John Silber were influenced by Strauss, but perhaps more important are the cadres of younger Straussians on congressional staffs, in conservative foundations, and in other centers of right-wing activism. They did not mature under a progressive liberal regime, and they perceive a "betrayal" of the Reaganera agenda. Thus, they often take more conservative positions. For insight into the polarization over Strauss's ideas, see the lively exchange between postmodernist Richard Rorty (1988) and Straussian Harvey C. Mansfield (1988) over Alan Bloom's (1987) Closing of the American Mind and Straussianism. For a liberal critique of Strauss, see Drury (1997). 
p. 261). By contrast to classical philosophical and biblical emphases on "virtue" and "restraint," he argued, liberals, from Hobbes onward, shifted the emphasis from "duty" and "wisdom" to "right" and "consent" and, thereby, removed the constraints on desire and pleasure. In his view, they eroded communal bonds and social norms, suppressed natural inequalities, and reduced life to a nihilistic "desire for self-preservation," "hedonism," or "joyless quest for joy" (Strauss [1950] 1965, pp. 181-88, 248-51). Reminiscent of radical conservative critiques of American cultural homogenization, Strauss saw the United States, during the height of postwar liberalism, as the "land of the philistines." He claimed that its "mass society" renders "irrelevant all natural differences and therefore in particular also the racial differences one can easily visualize a society consisting of racially different men and women each of whom dresses, has 'fun,' mourns, talks, feels, thinks and is buried like everyone else" (Strauss 1995, pp. 263, 272).

Young Strauss was influenced profoundly by Heidegger's Nietzschean critiques of Western rationalism and universalism. He stressed emphatically the importance of Heidegger's warnings about U.S. liberalism and Soviet communism producing a global "night of the world" or culturally homogenous civilization based on technocracy and utilitarian self-preservation (a fear shared by Schmitt and today's New Right; see Strauss $1989 b$, pp. 38-44). Strauss addressed Schmitt very seriously, engaging his arguments about the friend-enemy distinction, liberal depoliticization, and restoration of the political and criticizing him for being too mild in his critique of liberalism. ${ }^{28}$ The imprint of Strauss's youthful engagement with Heidegger and Schmitt appears in his mature antiliberalism and his critiques of cultural homogenization and depoliticization. By contrast, however, to Heidegger's and Schmitt's drift toward protofascist strains of postmodern politics and the total state, Strauss wanted to revive belief in the absolutist foundations or "truth" of classical Western political philosophy and religion, which he saw as the best counterforces to modern "historicism" and to the rampant erosion of moral authority (Strauss 1965, $1989 b$, pp. 24-26; 1989a, pp. 21-24).

Strauss criticized Max Weber's distinction between facts and values and, especially, his perspectivist view of modern culture as a "war between the gods" or perpetual "value conflict." Although respecting Weber's "noble nihilism," Strauss held, his "insight into the baseless character of everything noble" opens the door to nihilism and even fascism. Strauss feared that his historicism undercut all moral authority, preventing reason from mediating between or ranking values (Strauss 1965, pp. 42-43, 48, 64-68).

${ }^{28}$ Schmitt recognized the incisiveness of Strauss's critique and, in response, altered some facets of his political theory (Strauss 1996; Meier 1995; Drury 1997, pp. 65-96). 
Strauss saw Nietzsche as the ultimate author of noble nihilism. However, in his view, Nietzsche grasped its sweeping cultural and political consequences much more penetratingly than Weber, and, thus, averting futile efforts to justify modernity, exposed liberalism's profound exhaustion. Strauss implied that Heidegger and Schmitt followed Nietzsche's tracks. By contrast to these philosophers, however, he argued, average persons "cannot live without light, guidance, knowledge" or transcendental authority (Strauss 1965, p. 74). He considered them too weak to handle the perspectivist insight that knowledge and values are mere historical products of cultural groups, with no ultimate "truth" or "foundation." Strauss implied that this insight goes astray and even mad in mass culture, where nihilism is lived in an ignoble, destructive way. He thought that a culture where "everything is permitted" leads to the strongman and the gulag. He implied that modern liberalism cannot, ultimately, support democracy, but he also thought that Nietzsche's devastating critique of modernity precluded a simple return either to Enlightenment reason or to traditional culture. Strauss himself shared the historicist view that ideas and values were only human creations and stressed, like radical conservatives, that the consequent cultural differences and "regimes" are incommensurable and mutually impenetrable (converging ironically with his radical perspectivist enemies). But he wanted to shelter average people, incapable of bearing responsibly the weight of such potentially harmful "basic truths." Thus, he advocated the "noble lie" to obscure these truths, keeping them "between the lines" in texts accessible only to philosophical elites. Playing the role of a Nietzschean "ascetic priest," he aimed to counter liberalism's supposed apocalyptic breakdown of normative authority through cultivation of the belief that the "classics" contain timeless, binding, absolute Truths about the "good society." ${ }^{\prime 2} \mathrm{He}$ intended this simulated absolutism to substitute for modern theory's historicist and dialogical method, which, from his standpoint, leads inevitably to radical relativism, fragmentation, and nihilism (Strauss 1965, pp. 131-32; [1952] 1980, pp. 34-36; 1989b, pp. 25-26, 42; 1989a, pp. 32-34, 81-98; Drury 1997, pp. 91-96).

Strauss insisted that the classics were "not egalitarian" and that the

${ }^{29}$ Nietzsche held that ascetic priests create theodicies that forge and reproduce sociocultural solidarity by channeling mass resentment inward to guilt and outward against collective enemies. He called for a new type of postmodern philosophical elite to break radically from theodicy and all foundationalism. However, Strauss rejected such impulses and posed, as a cure for nihilism and historicism, the very foundationalist version of Truth that Nietzsche saw as priestly "ressentiment" and hoped to surpass. By contrast to Strauss's "noble lie," Nietzsche ([1887] 1969, p. 158) stressed authenticity: "All honor to the ascetic ideal insofar that it is honest! so long as it believes in itself and does not play tricks on us!" On Strauss and Nietzsche, see Lambert (1996, pp. 166-84). 
"best men" should rule over the "vulgar." He held that "equal rights" for everyone is "most unjust" and that politics should reconcile "the requirement for wisdom with the requirement for consent." Conversely to egalitarianism, he argued, under "classic natural right wisdom takes precedence over consent." In Strauss's view, the "classics rejected democracy" (i.e., because it gives primacy to "freedom" rather than to "virtue"), and they agreed that virtue, the true goal of political life, is best pursued by "aristocracy" (1965, pp. 140-42; 1989a, pp. 35, 39). He believed that the "best regime" is the "absolute rule of the wise" and that the "best practicable regime" is rule by "gentlemen" or the political "imitation" of a true philosophical elite. Sharing Schmitt's pessimism about human nature and seeing a great unalterable gulf between the "wise" (oriented to Truth) and "vulgar" (slaves to "lower impulses"), he held that political leaders must be ready to employ "forcible" or "despotic" restraint and suspend natural rights when threatened by "foreign enemies" and "subversive elements within society." But Strauss also stressed strategic compromises, implying that a "mixed regime," combining aristocracy and democracy, was the best for his day (1965, pp. 132-35, 140-42, 151-53, 160-61, 185).

Strauss's shadow can easily be detected in recent cultural wars over the canon and postmodernism. But his view of the classics as a repository of absolute political Truth suggests a more basic challenge to modern democracy than is raised by his neoconservative followers. His so-called noble lie obscures his ultimate perspectivist vision of culture, which converges with postmodernism's politicized strong program. His point that the governing ideals and norms of political regimes should be treated as absolute makes them the aegis of a narrow intellectual and political elite and closes them to wider public dialogue. Thus he breaks with the communication model. Strauss's emphasis on prudence opened the way for the muted version of his ideas manifested in the current neoconservative alliance. Writing in the postwar United States, where liberalism was hegemonic and seemed to be the only bulwark against communism, he acted the part of a critical ally. However, adopting a tactic similar to Benoist on "democracy," he inverted the conventional meaning of liberalism, distinguishing "ancient liberalism," or the above-mentioned aristocratic regime that he esteemed from "modern liberalism," which he attacked vociferously. His favorable references to liberalism moderate his outward tone and fend off charges of extremism. Although formally defending the "liberal" tradition against communism and fascism, he reappropriated antiliberal aspects of early Western thought and transfigured liberalism into aristocratic elitism. Rather than conservative revolution, he implied a constitutional regime where political "truths" would be safe from challenge and popular sovereignty or "consent" would be minimal. The Straussian regime stresses strict subordination of the individual to a rigid po- 
litical hierarchy. In a crisis of neoliberalism, his ideas could come to justify the ascendence of the more austere paleoconservative type of regime that he implied normatively. Overall, Strauss offers theoretical resources for sharp critiques of neoliberalism and postmodernism and poses a radical alternative to modern theory and modern democracy.

\section{An End of Liberalism?}

Although leading carrier strata and ascendent groups have not yet emerged on the neopopulist right, Hans-George Betz argues that these movements diverge from postwar populism and are reminiscent of Weimar-era politics (i.e., because of their global spread, anticapitalist critiques of economic restructuring, and appeal to disenchanted followers from divergent strata). He holds that neopopulism manifests a decomposing postwar political framework: "a dramatic increase in anxieties, insecurity, and pessimism about the future"; "postmodern" rejection of beliefs in "a future ideal society" and big "ideological projects"; shift from "organized" to "individualized capitalism"; and decline of left and right "cleavage politics" (Betz 1994, pp. 1-4, 23, 26-27, 34-35, 107, 141-68, 174-80; Betz 1998, p. 7; Betz and Immerfall 1998; Barber 1996, pp. 155-300).

In the 1980s, right-wing populist parties broadened their political bases among disenchanted strata, often shifting from neoliberal attacks on the welfare state to authoritarian racial, anti-immigrant, law-and-order agendas. This strategy helped increase their memberships, win some political offices, and push mainstream parties rightward. Although still marginal, some analysts predict that continued neoliberal globalization and further erosion of the left-right polarity will result in further expansion of these parties (Betz 1994, pp. 34-35, 189; 1998, p. 1; Immerfall 1998). Other thinkers make similar predictions about the New Right. Eatwell holds that these intellectual circles and consequent "partial rehabilitation of fascism" among elites opens the way for wider diffusion of neofascist ideas among the general public (Betz implies that right-wing populist parties are already more receptive to such ideas). Eatwell warns that the New Right is likely to gain much more political momentum in an "economic downturn," especially because the current centrist strategies of mainstream parties have raised expectations that neoliberal policies will ultimately improve labor markets and save welfare benefits. He fears that current signs indicate that significant facets of fascism will regain public support within 20 years (Eatwell 1997, pp. 352, 355, 361). Parsons and many other postwar modernization theorists saw free market capitalism and Social Darwinism to be moribund ideologies in the 1960s, but 1970s economic problems conjured them up from the grave. A periodical event since the origin of capitalism, market crises often take positions to the 
center of debate and struggle that did not recently hold sway. In a global economic crisis, the "opportunity society" could appear to be as exhausted as Keynesianism and planning did in the later 1970s and 1980s. The cry for political intervention would likely stimulate new theories on the left as well as the right. Under these conditions, the New Right and paleoconservative approaches discussed above might be taken up by historically important carrier strata and groups and, thus, enter public life. The recent electoral success of Jörg Haider's "Freedom Party" (i.e., over 27\% of the Austrian vote and a second-place finish) and its role in a new coalition government makes this scenario more plausible.

Divergent theorists, who pose an "end to history," an "end of left and right," and an "end of alternatives," suggest more than a failure of theoretical imagination. In particular, pessimistic theorists argue that the cultural bases and legitimacy of modern democratic ideals have been weakened or eroded. The New Right reshapes radical perspectivism and tribal tendencies into a monocultural critique of modernity; the forbidden aestheticized politics of ethnos are reshaped seductively to fit culturally postmodernized conditions. However, the memory of fascism, decades of immigration and hybridization, and vastly increased global socioeconomic interdependence make it highly unlikely that revived neofascism could repeat past history. Yet radical conservative ideas could harden the antidemocratic tendencies already present in today's economically polarized, racialized, and complexly gated social world. Some thinkers hold that the cinema's dystopian scenarios of postmodern apocalypse are thinly sublimated accounts of existing tendencies, offering a sharper projection of the fearful "revival of the political" than I have discussed above. They imply that Weber's garrison state looms quietly in our new-built environments, spatial politics, and security systems as well as in the noisier and bloodier tribal struggles of more distant lands (Davis 1992; Barber 1996).

My aim, however, is not a predictive one; I wish instead to illustrate a nascent theoretical alternative to postwar modernization theories and to positions that followed in their tracks. I have argued that neoliberalism and postmodernism were responses to an eroding postwar economic, political, and sociocultural complex and to failed beliefs in modernization. However, the postwar era ended sometime between the mid-1970s start of neoliberal restructuring and the revolutions of 1989 . Now entwined with dominant political-economic and sociocultural forces, neoliberalism and postmodernism can hardly be seen as "alternatives." The radical conservative and paleoconservative tendencies suggest a possible shift that should provoke reflexive modern and postmodernist theorists to re-engage the issue of the foundations of liberalism and democracy and the role of "social theory" in this discourse. 
Ironically, for all his criticisms of Nietzsche, Heidegger's own position remains eminently "Nietzschean" in at least one crucial respect: he accepts without question the standpoint of "total critique. ..." Thus, for both thinkers the essence of modernity is faithfully captured by the category of "nihilism": a wholesalc dissolution of the structures of value and belief that have traditionally made life meaningful. The method of "immanent critique" is rejected insofar as there is . . nothing about modernity as a social formation . . . worth redeeming." (Wolin 1990, p. 166)

The view of the future animating Heidegger's prototypical radical conservative "total critique" is not prefigured in modern culture and relies on a philosophical and aesthetic vision that urges radical rupture and de novo creation of a completely new postliberal or postmodern order. Rejecting such sweeping ideas of cultural exhaustion, "immanent" or "internal" critiques depart from facets of existing or emergent social conditions. For example, Mannheim spoke of critique being anchored in a "living principle" or "ideas and values" that express "in condensed form the unrealized and ... unfulfilled tendencies which represent the needs of each age" and that exist in a "dialectical" relation with dominant "ideologies" ([1936] 1955, p. 199). This historicist type of critique makes normative points by sociological arguments, which welcome counterclaims. It is the domain of "social theory."

Even Nietzsche did not break entirely with modernity. He embraced certain modern cultural resources, expressing high hopes about a more creative, authentic, freer future prefigured in late modernity's cultural diversity and autonomous individuality. Shedding these historicist threads in Nietzsche's otherwise highly pessimistic view of modernity, radical conservatives radicalized his total critique. Ignoring his vituperations about nationalism and regimentation, they advocated collective subjectivity, aestheticized politics, and militarized culture, which promised to absorb the individual into the mass. Their one-sided "Nietzscheanism" substituted insular cultural totalities and mythologized ethnos for his "sovereign individual" and hybrid "good European" (Antonio 1995, 2001).

Radical conservatives blended their one-sided Nietzschean views with a one-sided, deeply pessimistic appropriation from Weber that transmuted rationalization into homogenization. ${ }^{30}$ Universalizing Weber's "iron cage"

${ }^{30}$ I am not implying that all radical conservatives engaged Weber's texts closely. As with Nietzsche, much of his influence was indirect and based on generalized ideas about his thought ("in the air" of the Weimar era political and intellectual culture; see, e.g., Hughes 1977 , pp. 34-35, 278-335, 372-78). 
thesis, they dropped his qualifications about rationalization's historical ambiguities and divergent directions as well as his views about the affirmative facets of bureaucracy vis-à-vis patrimonialism. They ignored his fundamental distinction between limited state power and total states and argument that, within democratic regimes, bureaucratic jurisdiction and monocratic decision making (i.e. the "rule of small number"), block revolutionary change but clarify responsibility and make reform possible. They also scuttled his argument that "distinctly modern" secularization and cultural rationalization multiply specialized spheres of value and life, rationalize them according to their distinct internal logics, and enhance capacities to detect and cope with difference. Neither did they embrace his nuanced, highly qualified affirmation of science, which treated it as a normative resource of modernity, nurturing "ethical responsibility" as well as an instrumental advance, serving prosaic interests. Radical conservatives treated rationalization as a singular, relentless, deterministic march of nihilistic disenchantment, instrumentalization, and domination. Traces of this hyperpessimistic view appear in the 1920s writings of the Marxist Georg Lukács as well as in the era's radical conservative theorists, such as Spengler (1991), Heidegger, Schmitt. Rather than rationalization per se, Weber's nightmare "iron cage" was exactly the top-down cure for bourgeois ills suggested by Schmitt and his friends and by their extremeleft counterparts.

Providing an intellectual bridge between the far right and cultural left, this totalizing fusion of quasi-Nietzschean and quasi-Weberian theory is visible in convergent facets of radical conservatism's "technological civilization," the Frankfurt school's "one-dimensionality," the New Left's "technocracy," and postmodernism's "carceral" society. ${ }^{31}$ In particular, Heidegger had enormous influence on several generations of social and political philosophers (e.g., Marcuse, Adorno, Arendt, Foucault; see, e.g., Safranski 1998). His reading of Nietzsche and radicalized total critique impacted on critical theory and was a major formative influence on poststructuralism and postmodernism. Radical conservatism and radical cultural-left thought converge in total critiques, which treat modern democracy as so spent and false that alternatives are no longer foreshadowed in existing institutions and that the line with authoritarian regimes is blurred (e.g., Delfini and Piccone 1998, pp. 25-26, 40-41). Weber saw this type of total critique, which he traced "back to Nietzsche," as a leading tendency in the romantic antimodernism of the youth movement and left and right revolutionism of his day (Weber [1921] 1958b, p. 393). He warned

${ }^{31}$ On convergence between left and right Nietzscheanism, see, e.g., Thomas (1986), Habermas (1987a, 1989, 1990), Taylor (1991), Wolin (1990, 1996), Aschheim (1992), Ferry and Renaut (1997), and Taguieff (1997). 
that the consequent aesthetic radicalism countered the moderating tendencies that he detected in the nascent scaled-down version of "science" and "ethic of responsibility," which he embraced normatively. Weber attacked orthodox Marxism's and libertarianism's pseudohistoricist evolutionary warranties about a sunny modern future as vehemently as the new forms of irrationalism. He saw these seemingly opposed tendencies to contradict inquiry and the discursive basis of legitimate order under conditions of disenchantment and cultural pluralism (Weber [1904] 1949a; [1917] 1949b). The reenchanted authoritarian world that he feared was on the horizon came into being about decade after his death. We still live in its wake.

Expressing fears about today's revived "Nietzschean" sensibilities, Luc Ferry and Alain Renaut contend that radical postructuralists, borrowing heavily from Heidegger, executed a "total critique of the modern world" that treats "the democratic project" as an "ideology" or "illusion" and leaves "no place for an internal critique" (Ferry and Renaut 1990, p. xvi; Ferry 1994).

An entire current of our recent intellectual life thought it had learned from Nietzsche that one could not escape from the dissatisfaction of modernity without rejecting the logic of argumentative rationality in which modern consciousness, breaking with the traditional universe has chosen to situate itself. It has thus been possible to believe that opening the way for a postmodernity meant above all ferreting out differences and their richness from the leveling tyranny of identity. . . Our philosophical generation is that which can no longer forget that the hatred of argumentation means principally a return to authority. (Ferry and Renaut 1997, p. 106; emphasis in original) $)^{32}$

Reminiscent of Mannheim, Ferry and Renaut embrace "internal criticism" or "analyzing ... societies in the name of their own principles, in the name of promises, which they make and do not keep." Implying entwinement of historicism and the communication model, they hold that, to avert reliance on regimentation or force, normative debates must be animated by standpoints that, at least, prospectively, amplify determinate historical prospects nestled in existing or emergent sociocultural conditions. Ferry (1994, p. 8) states "by contrast to the dazzling mythical hope of a movement beyond the real world," internal criticism offers an "un-

\footnotetext{
${ }^{32}$ Ferry and Renaut add: "When we do not make a distinction between the public sphere of argumentation and media sphere of performance, when we denounce the first because of the defects of the second, we open the way to a method of managing conflicts that risks leaving but one procedure to arrive at their resolution: that of lining up divisions on both sides" (1997, p. 106; also see Ferry and Renault 1990, 1997, pp. 92-95; Habermas 1990; Rorty 1998).
} 
limited space for reflection and action." It focuses on arguments about sociocultural reality, which by contrast to apodictic intuition, are uncertain and plural, and, by contrast to aesthetic vision, are more than a matter of taste and call for inquiry and evidence. For these reasons, internal critique facilitates discursive exchange rather than assertion. It turns to "social theory," and advances the partial historicization begun by Marx and diverse theorists following in his tracks.

Postmodernists and radical conservatives treat Marx as the master theorist of misguided faith in modernization. Overweening optimism about modernity exists in his work, especially in the prominent theme that social resources accumulate geometrically with advanced capitalist rationalization and open the way for human emancipation. In particular, he saw modern science as a fundamental resource, animating material and social progress and lifting reflexivity and collective agency to heights that will one day end all prior history. However, Marx also attempted to make Hegel's pathbreaking historicism more specific and "social." He intended his materialism to follow history's tracks, to detect its actual structural features and contradictions, to expand its possibilities for reducing unnecessary suffering, and to make human agency more intelligent. His immanent critique called for sociological inquiry and argument, rather than transcendental or decisionistic approaches. Although problematic and incomplete, Marx's historicization arguably can be seen as the start of modern social theory. Later "critical theorists," embracing his method, call for continual historical reassessment of theory and criticize the ahistorical facets of his work as he did with Hegel's thought (e.g., Benhabib 1986; Antonio 1981, 1989, 1990).

The uneven historicization in Marx's social theory arises from a tension between his "pseudohistoricism," which provides evolutionary guarantees about the future that suspend the need for inquiry and debate and, thus, retain affinity for earlier absolutism, and his "radical historicism," which opens normative claims to inquiry and discussion on the basis of their sociocultural consequences. The pseudohistorical side of Marx's work appears in his claims about capitalism's "iron laws," inevitable proletarian revolution and emancipation, and his certainty about his materialist science. By contrast, his radical historicism is visible in his empirical inquiries about capitalism, analyses of class fragmentation and subclass conflicts, and his uncertainty about his own crisis theory. ${ }^{33}$ Marx's contradictory

${ }^{33}$ Engels's ([1890a] 1959a, pp. 396; [1890b] 1959b, pp. 399-400) letters to Conrad Schmidt and Joseph Bloch indicate that Marx and Engels were aware of the contrasting historicist themes in their work. Engels argued that Marx and he embraced the more radical form of historicism. However, he admitted that they sometimes spoke too deterministically and were "partly to blame" for new forms of "Marxism" (i.e., "amazing 
historicism manifests a still ongoing and, perhaps, enduring "transition" between phases of Enlightenment-from monistic civil religion to plural social theories. The disenchantment of modernity, especially of its normative content, has proceeded much more slowly and unevenly than Marx or the philosophes could ever have imagined. Referring to Nietzsche and Tolstoy, Weber's rumination about the "vocation" of science, its tendency to make death "meaningless," and antimodern reaction provides eloquent testimony to an inbetween age ([1918] 1958a). Reactionary tribalism reflects the mean side of the ambivalence about secular life in a time when the shadows of previous enchantment still dance on the wall.

From diverse points of view, other first-generation modern theorists also posed normative standpoints that claimed to reflect the progressive side of modernization-although sometimes much less assertively and in more roundabout ways than Marx did. Framed before the rise of specialized science and the world wars, these theorists had a strong faith in science and modernity, especially in the promise of increased reflexivity and rational agency and, consequently, greatly expanded capacities for enlightened sociopolitical intervention. After some tempering of meteoric hopes, resurgent, post-World War II era "grand theories" expressed fresh versions of evolutionary historicism, which had earlier plagued Marx. Optimism was so high about progressive modernization and social science's prominent role in the process that many empirically oriented theorists implied that there was no need for social theory. They heralded the dawning of a postideological age where consensus about liberal democratic values and institutions reduced debates over social problems to technical matters of implementation. Although applauding efforts to mine earlier modern theories for research problems, concepts, and hypotheses, they saw first-generation approaches as prescientific speculative frameworks, too normative and too broad to be "tested." Viewing social theory as something to be surpassed, they celebrated its decline and replacement by "sociological theory" as a sign of disciplinary modernization and progress (e.g., Catton 1966; Homans 1967; Merton 1967; see Ross 1991). Commenting on postwar U.S. sociology, Raymond Aron lamented the equation of the decline of "major doctrines," "grand syntheses," and "global historical interpretations of the modern age" with "scientific maturity" ([1967] 1989, pp. v-ix, 331-32). From left and right, C. Wright Mills (1961) and Robert Nisbet (1966) had similar regrets. Levine (1995, pp. 315-16) makes the same point today, holding that social theory's core problem of "coming to grips with the character of the modern order" is regrettably eschewed and even erased from the social science curriculum.

rubbish") that use materialism "as an excuse for not studying history" and as a "lever for construction after the manner of a Hegelian." 
Postmodernists charge that modern theory's quasi-evolutionary warranties about sociocultural progress, whether directly in the form of grand theory or tacitly as "value-free" scientism, merely dress absolutism in scientific garb and, thus, undermine dialogue about modernity's conflictive values, crisis tendencies, and repressive features. They hold that modern theory has been rife with particularist biases (e.g., racial, ethnic, religious, gender, colonial blindspots) and has failed to follow through in practice on the ethical universalism or ethical neutrality that it endorses in the abstract. They claim that it often "totalizes" hegemonic cultural views, helping repress difference and harden domination. Although these critiques are sometimes exaggerated, they point to genuine problems in the modern tradition. As I have argued above, "reflexive" modern theorists converge with reflexive postmodernists. Their attacks on pseudohistorical progressivism, scientism, and totalized theory do not entail a rejection of historicism or social theory in toto. Rather they scale down and historicize modern theory's normative claims, carrying on the critical side of Enlightenment thought. Modern theory is best grasped in a "postmodern" way, recognizing its ambiguous, discordant facets. However, identifying its blindspots and flaws ought to animate reconstruction rather than dismissal.

The total critique by the politicized version of strong-program postmodernism executes a sharp, albeit, incomplete break with modern theory, leaving its self-proclaimed hope for cultural transformation hanging without sociological bases. Putting aside Schmitt's normative affirmation of friend-enemy thinking, his theory offers insights into left tribalism. Suffusing its combative particularism, friend-enemy distinctions contradict its espoused ideals, foster political correctness, and undermine its hopedfor alliance politics. Although formally embracing multiculturalism, essentialized identity politics and standpoint philosophy break with the communication model upon which such cultural pluralism relies. Abandoning the historicist emphasis on the "factual" or consequential side of normative discourses, strong-program textualism lacks the constraint provided by systematic "sociological" inquiry about obdurate "realities." The resulting radical relativist position points limply to the social location of favored points of view, but it lacks pragmatic bases to justify their ranking over competing perspectives. Although advocating multisided plural "discourses," this strategy merely asserts normative standpoints and, thus, tends toward monologue. Its implicit reliance on authority paves the way for more extreme antiuniversalism, perspectivism, and culturalism. The radical conservative total critique overturns much more radically and consistently the sociological presuppositions of modern theory and of sociopolitical orders based on demos. Promising reenchantment and transcendence of nihilism, reactionary tribalism offers antidemocratic alter- 
natives to postmodernism's fractious heterotopia as well as to neoliberalism's global market and to social democracy's withered modernization project.

First-generation modern theories expressed an ethical dimension that amplified science's differentiation from politics and religion and that was narrated in reference to exemplary events, struggles, and people (i.e., the trial of Galileo). This motif also was manifested in beliefs about "truth seeking," which seem quaint and naive by today's constructivist standards, but which motivated theorists such as Marx, Weber, and Mead to struggle tirelessly with "problematics" and leave behind reams of unpublished work. Nietzsche saw this scientific "will to truth" as the secularized root of Judeo-Christian culture, and, despite his doubts, conceded its "integrity" in late modernity. During the postwar era, this ethical side of science was sublimated into an optimistic halo around economic growth and technocracy, and, after modernization theory crashed, it was seen as a complete fabrication by ascendent postmodernism. Assurances about progressive modernity and science lack force when such faith has dimmed nearly everywhere beyond disciplinary inner circles and in light of the antimodern challenges to democratic culture. But given today's cacophonous value splits and internecine tribal warfare, purely deconstructive strategies and radical relativism hardly seem "critical." Realism about science's ambiguous meanings, divergent impacts, and limits should not rule out efforts to reappropriate its ethical side or to entertain its potential resources for public life. Rethinking social theory as a normative language and mediator between science and plural, segmented publics is a project worth pursuing in today's climate.

First-generation modern theory arose from a broader cultural shift from absolutist standpoints based on theological and metaphysical presuppositions to historicist normative arguments. Social theory is no substitute for specialized knowledge or empirical work, but it provides a means to discuss science's purposes, directions, and role-normative issues that are beyond the purview of science per se. By contrast to sociological theory's largely empirical, hermeneutic, or analytical intent and middle-range disciplinary focus, social theory has a strong normative thrust. It poses broad questions about the "value" of different directions of sociocultural development, knowledge, and policy. The line with philosophy is often ambiguous, but social theory is a historicist alternative to religious or metaphysical absolutism and to transcendental or deontological theories. It has philosophical presuppositions, but it debates normative matters primarily on the basis of existent, nascent, or possible sociocultural conditions and, thus, draws on social-scientific theories, concepts, and research. Social theory also differs from more narrowly bounded and often ahistorical normative political theory. In a disenchanted age with diverse groups and 
values, social theory operates most effectively in pluralistic discursive fields of competing approaches, which parallel the diversity of civil society and provide nondogmatic, yet systematic means to address sociocultural differences. Social theories offer sociological "good reasons" for securing, reforming, or changing a sociocultural regime, and are, in principle, open to inquiry and challenge (i.e., debates center on its fit to sociocultural conditions and, especially, on its consequences for collective life). In my view, social theory is a distinctly modern practice that began with the first-generation modern theorists and is entwined with the rise of social science. As Weber implied, new social theories emerge in times of "rupture," when specialized knowledge and practices are crisis ridden and must be rethought to fit new conditions, but they also offer means to discuss and debate alternative directions of science and policy in good times as well as bad. Social theory cannot replace sociological theory or science, but it is a means for reflecting on their relation to public life. Although boundaries are porous, conflation of social theory and sociological theory distorts social knowledge. Treating social theory as a specific practice would reduce the tendency of normative theorists and empirical theorists to "speak past each other" (e.g., automatic dismissals of social theory for being "too broad," "too distant from testable problems," or "too philosophical" or, conversely, of specialized sociological work for being "too narrow," "too quantitative," or "too technical"). Pitting the two types of theory against each other amplify confusion about their role, meaning, uses, and limits.

We have moved only very haltingly toward the "secular ethic" and "dialogical" approach embraced by Levine. That we have not gotten very far appears in the rampant conflation of normative and empirical issues and of social theory with sociological theory. A residue of early modern theory, the lingering "faith" among specialists about the inherent cultural significance of their work and about social science's role as the beacon of late-modernity's reflexive agency looms over the postmodern cultural landscape-the specter of progress at the end of history. Both Nietzsche and Weber held that normative questions about "how we should live" or "what is worth knowing" cannot be answered by science, but are essential to reflexivity about its practices. The rampant endings' discourses and new total critiques reflect an exhaustion of theoretical imagination as much as social gridlock. However, the recent stirring of thought about modernity and postmodernity could mark the type of moment that Weber argued would cause us to look down from the "heights of thought" and rethink the "meaning" of our practices. Social theory and the communication model offer a via media against the rising tides of relativism and absolutism (e.g., Kloppenberg 1986; Kent 2000). John Dewey's point on the eve of the Depression still holds: "The need for large and generous 
ideas in the direction of life was never more urgent than in the confusion of tongues, beliefs, and purposes that characterizes present life" ([1929] $1988 b$, p. 248).

\section{REFERENCES}

Anderson, Perry. 1998a. "A Reply to Bobbio." New Left Review 231:91-93.

- 1998b. "A Sense of the Left." New Left Review 231:73-81.

Antonio, Robert J. 1981. "Immanent Critique as the Core of Critical Theory: Its Origins and Developments in Hegel, Marx and Contemporary Thought." British Joumal of Sociology 32:330-45.

- 1989. "The Normative Foundations of Emancipatory Theory: Evolutionary versus Pragmatic Perspectives." American Joumal of Sociology 94:721-48.

-1990. "The Decline of the Grand Narrative of Emancipatory Modernity: Crisis or Renewal in Neo-Marxian Theory?" Pp. 88-116 in Frontiers of Social Theory: The New Syntheses, edited by George Ritzer. New York: Columbia University Press.

- 1991. "Postmodern Storytelling versus Pragmatic Truth-Seeking: The Discursive Bases of Social Theory." Sociological Theory 9:154-63.

- 1995. "Nietzsche's Antisociology: Subjectified Culture and the End of History." American Journal of Sociology 101:1-43.

- 1998. "Mapping Postmodern Social Theory." Pp. 22-75 in What Is Social Theory? The Philosophical Debates, edited by Alan Sica. Oxford: Blackwell.

- 2001. "Nietzsche: Social Theory in the Twilight of the Millennium." In The Handbook of Social Theory, edited by George Ritzer and Barry Smart. London: Sage, in press.

Antonio, Robert J., and Alessandro Bonanno. 1996. "Post-Fordism in the United States: The Poverty of Market-Centered Democracy." Current Perspectives in Social Theory 16:3-32.

Antonio, Robert J., and Douglas Kellner. 1992a. "Communication, Modernity, and Democracy in Habermas and Dewey." Symbolic Interaction 15:277-97.

- 1992b. "Metatheorizing Historical Rupture: Classical Theory and Modernity." Pp. 88-106 in Metatheorizing, edited by George Ritzer. Newbury Park, Calif.: Sage.

Appiah, K. Anthony, and Amy Guttman. 1996. Color Conscious: The Political Morality of Race. Princeton, N.J.: Princeton University Press.

Aron, Raymond. (1967) 1989. Main Currents in Sociological Thought, vol. 2. Translated by Richard Howard and Helen Weaver. New York: Anchor Books.

Aschheim, Steven E. 1992. The Nietzsche Legacy in Germany, 1890-1990. Berkeley and Los Angeles: University of California Press.

Ashley, David. 1997. History without a Subject: The Postmodern Condition. Boulder, Colo.: Westview Press.

Barber, Benjamin R. 1996. Jihad vs. McWorld: How Globalism and Tribalism Are Reshaping the World. New York: Ballantine Books.

Baudrillard, Jean. 1983a. In the Shadow of the Silent Majorities or, The End of the Social and Other Essays, translated by Paul Foss, John Johnston, and Paul Patton. New York: Semiotext(e).

- 1983b. Simulations, translated by Paul Foss, Paul Patton, and Phillip Beitchman. New York: Semiotext(e).

_ 1990. Fatal Strategies, edited by Jim Fleming. Translated by Philip Beitchman and W. G. J. Niezluchowsky. New York and London: Semiotext(e)/Pluto.

Bauman, Zygmunt. 1992. Intimations of Postmodernity. New York: Routledge.

- 1993. Postmodern Ethics. Oxford: Blackwell.

Beck, Ulrich. 1992a. "From Industrial Society to the Risk Society: Questions of 
Survival, Social Structure and Ecological Enlightenment." Theory, Culture and Society 9 (1): 97-123.

- 1992b. Risk Society: Towards a New Modernity, translated by Mark Ritter. Thousand Oaks, Calif.: Sage.

1. 1994. "The Reinvention of Politics: Towards a Theory of Reflexive Modernization." Pp. 1-55 in Reflexive Modernization: Politics, Tradition and Aesthetics in the Modern Social Order, edited by Ulrich Beck, Anthony Giddens, and Scott Lasch. Stanford, Calif.: Stanford University Press.

1996. "World Risk Society as Cosmopolitan Society? Ecological Questions in a Framework of Manufactured Uncertainties." Theory, Culture and Society 13 (4): 1-32.

. 1997. The Reinvention of Politics: Rethinking Modernity in the Global Social Order, translated by Mark Ritter. Cambridge: Polity Press.

Beck, Ulrich, Anthony Giddens, and Scott Lash. 1994. Reflexive Modernization: Politics, Tradition and Aesthetics in the Modern Social Order. Stanford, Calif.: Stanford University Press.

Bell, Daniel. 1990. "Resolving the Contradictions of Modernity and Modernism." Society 27 (March/April): 43-50.

Books.

Bell, Daniel A. 1995. Communitarianism and Its Critics. Oxford: Clarendon Press.

Bellah, Robert N., Richard Madsen, William M. Sullivan, Ann Swidler, and Steven M. Tipton. 1986. Habits of the Heart; Individualism and Commitment in American Life. New York: Perennial Library.

Bendersky, Joseph. W. 1987. "Carl Schmitt and the Conservative Revolution." Telos 72:27-42.

Benhabib, Seyla. 1986. Critique, Norm, and Utopia: A Study in the Foundations of Critical Theory. New York: Columbia University Press.

, ed. 1996. Democracy and Difference: Contesting the Boundaries of the Political. Princeton, N.J.: Princeton University Press.

Benhabib, Seyla, and Fred Dallmayr, eds. 1990. The Communicative Ethics Controversy. Cambridge, Mass.: MIT Press.

Bennett, David H. 1995. The Party of Fear: From Nativist Movements to the New Right in American History. New York: Vintage Books.

Benoist, Alain de. 1991. "Democracy: Ancient and Modern." Conservative Review 2 (6): 26-30.

- 1993-94a. "The Idea of Empire." Telos 98/99:81-98.

- 1993-94b. "Three Interviews with Alain de Benoist." Telos 98/99:173-207.

—. 1995. "End of the Left-Right Dichotomy: The French Case." Telos 102:73-89.

_. 1996a. "Confronting Globalization." Telos 108:117-37.

- 1996b. Europe, Tiers monde meme combat. Laffont: Paris.

. 1997. "The Time of the Nets" (in Italian). Diorama Letterario, no. 208 (http://www.diorama.it).

- 1998a. "Hayek: A Critique." Telos 110:71-104.

-1998b. "Between the Gods and the Titans," pt. 1. The Scorpion, issue 15.

—. 1998c. "Between the Gods and the Titans," pt. 2. The Scorpion, issue 17.

- 1999. "What Is Racism?" Telos 114:11-48.

Best, Steven, and Douglas Kellner. 1991. Postmodern Theory: Critical Interrogations. London: Macmillan.

Betz, Hans-George. 1994. Radical Right-Wing Populism in Western Europe. New York: St. Martin's Press.

- 1998. Introduction to The New Politics of the Right: Neo-Populist Parties and Movements in Established Democracies, edited by Hans George Betz and Stefan Immerfall. New York: St. Martin's Press. 
Betz, Hans-George, and Stefan Immerfall, eds. 1998. The New Politics of the Right: Neo-Populist Parties and Movements in Established Democracies. New York: St. Martin's Press.

Bloom, Allan David. 1987. The Closing of the American Mind: How Higher Education Has Failed Democracy and Impoverished the Souls of Today's Students. New York: Simon \& Schuster.

- 1989. "Responses to Fukuyama [Bloom's section]." National Interest 16:19-21.

Bobbio, Norberto. 1996. Left and Right: The Significance of a Political Distinction, translated by Allan Cameron. Chicago: University of Chicago Press.

- 1998. "At the Beginning of History." New Left Review 231:82-90.

Boyer, Robert. 1998. "The Pyrrhic Victory of Anglo-Saxon Capitalism." Thesis Eleven 53:93-101.

Boynton, Robert S. 1997. "The Two Tonys." New Yorker October 6:66-74.

Boyte, Harry C., and Frank Riessman, eds. 1986. The New Populism: The Politics of Empowerment. Philadelphia: Temple University Press.

Braun, Denny. 1997. The Rich Get Richer: The Rise of Income Inequality in the United States and the World, 2d ed. Chicago: Nelson-Hall Publishers.

Brenner, Robert. 1998. Special issue, "The Economics of Global Turbulence: A Special Report on the World Economy, 1950-98." New Left Review, vol. 229.

Brohman, John. 1996. Popular Development: Rethinking the Theory and Practice of Development. Oxford: Blackwell.

Buchanan, Patrick J. 1998. The Great Betrayal: How American Sovereignty and Social Justice Are Being Sacrificed to the Gods of the Global Economy. Boston: Little Brown.

Butler, Judith. 1998. "Merely Cultural." New Left Review 227:33-44.

Castells, Manuel. 1996. The Information Age: Economy, Society and Culture: The Rise of Network Society. Oxford: Blackwell.

- 1997. The Information Age: Economy, Society and Culture: The Power of Identity. Oxford: Blackwell.

-1998. The Information Age: Economy, Society and.Culture: End of Millennium. Oxford: Blackwell.

Catton, William B. 1966. From Animistic to Naturalistic Sociology. New York: McGraw-Hill.

Charnot, Paul. 1998. "Eclectics in Perspective." The Scorpion, issue 17.

Coppola, Vincent. 1996. Dragons of God: A Joumey through Far-Right America. Marietta, Ga.: Longstreet Press.

Dahl, Göran. 1996. "Will 'the Other God' Fail Again? On the Possible Return of the Conservative Revolution." Theory, Culture, and Society 13 (1): 25-50.

1999. Radical Conservatism and the Future of Politics. London and Thousand Oaks, Calif.: SAGE Publishers.

Davis, Mike. 1992. City of Quartz: Excavating the Future in Los Angeles. New York: Vintage Books.

Delfini, Alex, and Paul Piccone. 1998. "Modernity, Libertarianism and Critical Theory: Reply to Pellicani." Telos 112:23-46.

Dewey, John. (1938) 1986. Logic: The Theory of Inquiry. Vol. 12 of John Dewey, The Later Works, 1925-1953, edited by Jo Ann Boydston. Carbondale and Edwardsville: Southern Illinois University Press.

- (1925) 1988a. Experience and Nature. Vol. 1 of John Dewey: The Later Works, 1925-1953, edited by Jo Ann Boydston. Carbondale and Edwardsville: Southern Illinois University Press.

- (1929) 1988b. The Quest for Certainty. Vol. 4 of John Dewey: The Later Works, 1925-1953, edited by Jo Ann Boydston. Carbondale and Edwardsville: Southern Illinois University Press. 
Dickens, R. David, and Andrea Fontana, eds. 1994. Postmodernism and Social Inquiry. New York: Guilford Press.

Drury, Shadia B. 1997. Leo Strauss and the American Right. New York: St. Martin's Press.

Eagleton, Terry. 1996. The Illusions of Postmodernism. Oxford: Blackwell.

Eatwell, Roger. 1997. Fascism: A History. New York: Penguin Books.

The Economist. 1998. "Beyond Left and Right." May 2-8, pp. 52-53.

Engels, Frederick. (1890a) 1959a. "Engels to Conrad Schmidt." Pp. 395-97 in Marx and Engels: Basic Writings on Politics and Philosophy, edited by Lewis S. Feuer. Garden City, N.Y.: Anchor Books.

- (1890b) 1959b. "Engels to Joseph Bloch." Pp. 397-400 in Marx and Engels: Basic Writings on Politics and Philosophy, edited by Lewis S. Feuer. Garden City, N.Y.: Anchor Books.

Etzioni, Amitai, ed. 1995. Rights and the Common Good: The Communitarian Perspective. New York: Saint Martin's Press.

Feher, Ferenc. 1995. "1989 and the Deconstruction of Political Monism." Thesis Eleven 42:87-112.

Ferry, Luc. 1994. "The Three Phases of Modern Philosophy: Tasks for a Secularized Thought." Thesis Eleven 37:1-9.

Ferry, Luc, and Alain Renaut. 1990. French Philosophy of the Sixties: An Essay on Antihumanism, translated by Mary H. S. Cattani. Amherst: University of Massachusetts Press.

- 1997. "What Must First Be Proved Is Worth Little." Pp. 92-109 in Why We Are Not Nietzscheans, edited by Luc Ferry and Alain Renaut. Translated by Robert de Loaiza. Chicago: University of Chicago Press.

Francis, Samuel. 1993. Beautiful Losers: Essays on the Failure of American Conservatism. Columbia: University of Missouri Press.

Frankel, Boris. 1997. "Confronting Neoliberal Regimes: The Post-Marxist Embrace of Populism and Realpolitik." New Left Review 226:57-92.

Fraser, Nancy. 1995. "From Redistribution to Recognition, Dilemmas of Justice in a 'Post-Socialist' Age." New Left Review 212:68-93.

1997. Justice Intermuptus: Critical Reflections on the "Postsocialist" Condition. Routledge: New York.

- 1998. "Heterosexism, Misrecognition and Capitalism: A Response to Judith Butler." New Left Review 228:140-49.

Fukuyama, Francis. 1989. "The End of History?" National Interest 16:3-18.

- 1992. The End of History and the Last Man. London: Penguin Books. 16-33.

Giddens, Anthony. 1991. Modemity and Self Identity: Self and Society in the Late Modern Age. Stanford, Calif.: Stanford University Press.

- 1992. The Transformation of Intimacy: Sexuality, Love and Eroticism in Modern Societies. Stanford, Calif.: Stanford University Press.

- 1994a. Beyond Left and Right: The Future of Radical Politics. Stanford, Calif.: Stanford University Press.

— 1994b. "Living in a Post-Traditional Society." Pp. 56-109 in Reflexive Modernization: Politics, Tradition and Aesthetics in the Modern Social Order, edited by Ulrich Beck, Anthony Giddens, and Scott Lash. Stanford, Calif.: Stanford University Press.

Gitlin, Todd. 1995. The Treilight of Common Dreams: Why America Is Wracked by Culture Wars. New York: Metropolitan Books.

Gordon, David M. 1996. Fat and Mean: The Corporate Squeeze of Working Americans and the Myth of Managerial "Downsizing." New York: Free Press.

Gottfried, Paul. 1990. Carl Schmitt: Politics and Theory. New York: Greenwood Press. 
1993. "Anatomy of an Apology [review of Stephen Holmes, The Anatomy of Antiliberalism]." Telos, no. 97, pp. 155-64.

—. 1994. "After Liberalism." Telos, no. 101, pp. 169-72.

- 1995. "Reconfiguring the Political Landscape" Telos, no. 103, pp. 111-26.

. 1996. "The Best of All Possible Worlds [Review of Max Singer and Aaron Wildavsky, The Real World Order]." Telos, no. 109, pp. 189-92.

Greider, William. 1997. "Why the Global Economy Needs Worker Rights." Working USA May/June: 32-44.

Gutmann, Amy, ed. 1994. Multiculturalism: Examining the Politics of Recognition. Princeton, N.J.: Princeton University Press.

Habermas, Jürgen. 1984. The Theory of Communicative Action: Reason and the Rationalization of Society, vol. 1. Thanslated by Thomas McCarthy. Boston: Beacon Press.

- 1987a. The Philosophical Discourse of Modemity: Thelve Lectures, translated by Frederick Lawrence. Cambridge, Mass.: MIT Press.

. 1987b. The Theory of Communicative Action: Lifeworld and System: A Critique of Functionalist Reason, vol. 2. Translated by Thomas McCarthy. Boston: Beacon Press.

- 1989. The New Conservatism: Cultural Criticism and the Historians Debate, edited and translated by Shierry Weber Nicholsen. Cambridge, Mass.: MIT Press.

1990. "What Does Socialism Mean Today? The Rectifying Revolution and the Need for New Thinking on the Left." New Left Review 183:3-21.

- 1993. "Struggles for Recognition in Constitutional States." European Journal of Philosophy 1:128-55.

1996. Between Facts and Norms. Contributions to a Discourse Theory of Law and Democracy, translated by William Rehg. Cambridge, Mass.: MIT Press.

. 1998. "Remarks on Legitimation through Human Rights." Philosophy and Social Criticism 24 (2/3): 157-71.

Haraway, Donna. 1988. "Situated Knowledges: The Science Question in Feminism and the Privilege of Partial Perspective." Feminist Studies 14:575-99.

Harrison, Bennett. 1994. Lean and Mean: The Changing Landscape of Corporate Power in the Age of Flexibility. New York: Basic Books.

Harrison, Bennett, and Barry Bluestone. 1988. The Great U-Turn: Corporate Restructuring and the Polarizing of America. New York: Basic Books.

Harvey, David. 1989. The Condition of Postmodernity: An Enquiry into the Origins of Cultural Change. Cambridge, Mass.: Blackwell.

Heidegger, Martin. (1953) 1961. An Introduction to Metaphysics, translated by Ralph Manheim. Garden City, N.Y.: Anchor Books.

Herf, Jeffrey. 1986. Reactionary Modemism: Technology, Culture, and Politics in Weimar and the Third Reich. New York: Cambridge University Press.

Hobsbawn, E. J. 1996. "Identity Politics and the Left.” New Left Review 217:38-47.

Homans, George C. 1967. The Nature of Social Science. New York: Harbinger Books.

Hughes, H. Stuart. 1977. Consciousness and Society: The Reorientation of European Social Theory, 1890-1930. New York: Vintage Books.

Hughey, Michael W., ed. 1998. New Tribalisms: The Resurgence of Race and Ethnicity. New York: New York University Press.

Immerfall, Stefan. 1998. "The Neo-Populist Agenda." Pp. 249-61 in The New Politics of the Right: Neo-Populist Parties and Movements in Established Democracies, edited by Hans George Betz and Immerfall. New York: St. Martin's Press.

Jameson, Fredric. 1984. "Postmodernism, or the Cultural Logic of Late Capitalism." New Left Review 146:53-92.

1991. Postmodernism, or, the Cultural Logic of Late Capitalism. Durham, N.C.: Duke University Press.

Jencks, Charles. 1986. Modern Movements in Architecture. Harmondsworth: Penguin. 
Kalb, James. 1998. "The Amish, David Koresh, and a Newer World Order." The Scorpion, issue 19.

Kalyvas, Andreas. 1999. "Review Essay: Who's Afraid of Carl Schmitt." Philosophy and Social Criticism 25 (5): 87-113.

Kent, Robert. 2000. "John Dewey and the Project of Critical Social Theory." Social Thought and Research 23:1-58.

Kloppenberg, James T. 1986. Uncertain Victory: Social Democracy and Progressivism in European and American Thought, 1870-1920. New York: Oxford University Press.

Kolnai, Aurel. 1938. The War against the West. New York: Viking.

Kumar, Krishan. 1995. From Post-Industrial to Post-Modern Society: New Theories of the Contemporary World. Oxford: Blackwell.

Lambert, Laurence. 1996. Leo Strauss and Nietzsche. Chicago: University of Chicago Press.

Lasch, Christopher. 1995. The Revolt of the Masses and the Betrayal of Democracy. New York: Norton.

Lee, Martin A. 1997. The Beast Reawakens. Boston: Little, Brown.

Lefebvre, Henri. (1962) 1995. Introduction to Modernity: Twelve Preludes, September 1959-May 1961, translated by John Moore. New York: Verso.

Leinberger, Paul, and Bruce Tucker. 1991. The New Individualists: The Generation after the Organization Man. New York: HarperCollins.

Lepenies, Wolf. 1988. Between Literature and Science: The Rise of Sociology, translated by R. J. Hollingdale. New York: Cambridge University Press.

Levine, Donald N. 1995. Visions of the Sociological Tradition. Chicago: University of Chicago Press.

- 1997. "Social Theory as a Vocation: Engaging with Future Challenges." Perspectives: The ASA Theory Section Newsletter 19:1-8.

Lyotard, Jean-François. 1984. The Postmodern Condition: A Report on Knowledge, translated by Geoff Bennington and Brian Massumi. Minneapolis: University of Minnesota Press.

MacIntyre, Alasdair. 1988. Whose Justice? Which Rationality? Notre Dame, Ind: University of Notre Dame Press.

Maffesoli, Michel. 1996. The Time of the Tribes: The Decline of Individualism in Mass Society, translated by Don Smith. Thousand Oaks, Calif.: Sage.

Mannheim, Karl. (1936) 1955. Ideology and Utopia: An Introduction to the Sociology of Knowledge, translated by Louis Wirth and Edward Shills. New York: Harvest Books.

Mansfield, Harvey, Jr. 1988. "Straussianism, Democracy, and Allan Bloom, II: Democracy and the Great Books." New Republic 198 (14): 33-37.

Marx, Karl, and Frederick Engels. (1848) 1976. Manifesto of the Communist Party. Pp. 477-519 in Karl Marx Frederick Engels: Collected Works, 50 vols. Vol. 6, Marx and Engels: 1845-1848. New York: International Publishers.

Meier, Heinrich. 1995. Carl Schmitt and Leo Strauss: The Hidden Dialogue. Chicago: University of Chicago Press.

Mellucci, Alberto. 1996. Challenging Codes: Collective Action in the Information Age. New York: Cambridge University Press.

Merton, R. 1967. On Theoretical Sociology: Five Essays, Old and New. New York: Free Press.

Mills, C. Wright. 1961. The Sociological Imagination. New York: Grove Press.

Mouffe, Chantal. 1993. The Return of the Political. London: Verso.

Mulhall, Stephen, and Adam Swift. 1992. Liberals and Communitarians. Oxford: Blackwell.

Nicholson, Linda. 1996. "To Be or Not to Be: Charles Taylor and the Politics of Recognition." Constellations 3 (1): 1-16.

Nietzsche, Friedrich. (1887) 1969. On the Genealogy of Morals, translated by Walter 
Kaufmann and R. J. Hollingdale, and (1888) Ecce Homo, translated by Walter Kaufmann. New York: Vintage Books.

Nisbet, Robert. 1966. The Sociological Tradition. New York: Basic Books.

Offe, Claus. 1996. Modernity and the State: East, West. Cambridge, Mass.: MIT Press. Paretsky, Nick. 1996. "Support For Industrial Policy by the Council on Foreign

Relations and Trilateral Commission: 1974-1984." Unpublished paper presented at the American Sociological Meetings, New York, August 16-20.

Parsons, Talcott. 1971. The System of Modern Societies. Englewood Cliffs, N.J.: Prentice-Hall.

Pels, Dick. 1998. "Fascism and the Primacy of the Political." Telos 110:39-70.

\section{$86: 127-40$.}

. 1995. "Postmodern Populism." Telos 103:45-86.

Rawls, John. 1971. A Theory of Justice. Cambridge, Mass.: Harvard University Press.

. 1996. Political Liberalism. New York: Columbia University Press.

Richardson, Laurel. 1991. "Postmodern Social Theory: Representational Practices." Sociological Theory 9:173-79.

Rorty, Richard. 1988. "Straussianism, Democracy, and Allan Bloom, I. That Old-Time Philosophy." New Republic 198 (14): 28-33.

- 1998. Achieving Our Country: Leftist Thought in Twentieth Century America. Cambridge, Mass.: Harvard University Press.

Ross, Dorothy. 1991. The Origins of American Social Science. New York: Cambridge University Press.

Safranski, Rüdiger. 1998. Martin Heidegger: Between Good and Evil, translated by Ewald Osers. Cambridge, Mass.: Harvard University Press.

Sandel, Michael J. 1996. Democracy's Discontent: America in Search of a Public Philosophy. Cambridge, Mass.: Belknap Press.

. (1982) 1998. Liberalism and the Limits of Justice, 2d ed. New York: Cambridge University Press.

Schlesinger, Arthur M., Jr. 1992. The Disuniting of America: Reflections on a Multicultural Society. New York: Norton.

Schmitt, Carl. (1925) 1986. Political Romanticism, translated by Guy Oaks. Cambridge, Mass.: MIT Press.

- (1926) 1988. The Crisis of Parliamentary Democracy, translated by Ellen Kennedy. Cambridge, Mass.: MIT Press.

- (1932) 1996. The Concept of the Political, notes and translation by George Schwab [with Leo Strauss's notes on Schmitt's essay, translated by J. Harvey Lomax]. Chicago: University of Chicago Press.

Seidman, Steven. 1991a. "The End of Sociological Theory: The Postmodern Hope." Sociological Theory 9:131-46.

The Politics of Epistemology." Sociological Theory 9:180-90.

1992. "Word Power: Is Rhetoric All There Is?" Sociological Theory 10:255-58.

- 1996a. "The Political Unconscious of the Human Sciences." Sociological Quarterly 37:699-719.

Q 1996b. "Pragmatism and Sociology: A Response to Clough, Denzin and Richardson." Sociological Quarterly 37:753-59.

Selznick, Philip. 1992. The Moral Commonwealth: Social Theory and the Promise of Community. Berkeley and Los Angeles: University of California Press.

Smart, Barry. 1992. Modern Conditions, Postmodern Controversies. New York: Routledge.

Spengler, Oswald. 1991. The Decline of the West, abridged edition by Helmut Werner, translated by Charles Francis Atkinson, and English abridged edition by Arthur Helps. New York: Oxford University Press. 
Stephens, Julie. 1998. Anti-Disciplinary Protest: Sixties Radicalism and Postmodernism. New York: Cambridge University Press.

Strauss Leo. (1950) 1965. Natural Right and History. Chicago: University of Chicago Press.

Press.

. (1952) 1980. Persecution and the Art of Writing. Chicago: University of Chicago

edited by Hilail Gildin. Detroit: Wayne State University Press. Press.

- 1989b. The Rebirth of Classical Political Rationalism: An Introduction to the Thought of Leo Strauss (Essays and Lectures by Leo Strauss), selected by Thomas L. Pangle. Chicago: University of Chicago Press.

Press.

(1968) 1995. Liberalism Ancient and Modern. Chicago: University of Chicago

(1932) 1996. "Notes on Carl Schmitt," translated by J. Harvey Lomax. Pp

81-107 in The Concept of the Political, by Carl Schmitt. Chicago: University of Chicago Press.

Strong, Tracy B., ed. 1992. The Self and the Political Order. Cambridge, Mass.: Blackwell.

Sunic, Tomislav. 1990. Against Democracy and Equality: The European New Right. New York: Peter Lang.

Taguieff, Pierre-André. 1993-94a. "From Race to Culture: The New Right's View of European Identity." Telos 98-99:99-125.

-1993-94b. "Origins and Metamorphoses of the New Right: An Interview with Pierre-André Taguief." Telos 98-99:159-72.

. 1997. "The Traditionalist Paradigm-Horror of Modernity and Neoliberalism:

Nietzsche in Reactionary Rhetoric." Pp. 158-224 in Why We Are Not Nietzscheans, edited by Luc Ferry and Alain Renaut and translated by Robert De Loaiza. Chicago: University of Chicago Press.

Taylor, Charles. 1991. The Ethics of Authenticity. Cambridge, Mass.: Harvard University Press.

Thomas, R. Hinton. 1986. Nietzsche in German Politics and Society 1890-1918. La Salle, Ill.: Open Court Press.

Turner, Stephen. 1996. "Religious Pluralism, Toleration, and Liberal Democracy: Past, Present, and Future." Pp. 275-89 in Religion and the Political Order: Politics in Classical and Contemporary Christianity, Islam, and Judaism, edited by Jacob Neusner. Tampa: University of South Florida Press.

Walzer, Michael. 1997. On Toleration. New Haven, Conn.: Yale University Press.

Weber, Max. (1904) 1949a. "'Objectivity' in Social Science and Social Policy." Pp. 49-112 in The Methodology of the Social Sciences, translated and edited by Edward A. Shils and Henry A. Finch. New York: Free Press.

- (1917) 1949b. "The Meaning of 'Ethical Neutrality' in Sociology and Economics." Pp. 1-47 in The Methodology of the Social Sciences, translated and edited by Edward A. Shils and Henry A. Finch. New York: Free Press.

—_. (1918) 1958a. "Science as a Vocation." Pp. 129-56 From Max Weber: Essays in Sociology, edited and translated by H. H. Gerth and C. Wright Mills. New York: Oxford University Press.

- (1921) 1958b. "National Character and the Junkers." Pp. 386-95 in Max Weber, From Max Weber: Essays in Sociology, edited and translated by H. H. Gerth and C. Wright Mills,. New York: Oxford University Press.

- (1922-23) 1958c. "The Social Psychology of World Religions." Pp. 267-301 in From Max Weber: Essays in Sociology, edited and translated by $\mathrm{H}$. H. Gerth and C. Wright Mills. New York: Oxford University Press.

West, Cornel. 1989. The American Evasion of Philosophy: A Genealogy of Pragmatism. Madison: University of Wisconsin Press. 
1993. Beyond Eurocentrism and Multiculturalism: Prophetic Thought in Postmodern Times, vol. 1: Monroe, Maine: Common Courage Press.

Woltermann, Chris. 1993. "What Is Paleoconservatism?" Telos 97:9-31.

Wood, Ellen Meiksins. 1986. The Retreat from Class: A New "True" Socialism. London: Verso.

1995. Democracy against Capitalism: Renewing Historical Materialism. New York: Cambridge University Press.

Woods, Roger. 1996. The Conservative Revolution in the Weimar Republic. New York: St. Martin's Press.

Wolin, Richard. 1990. The Politics of Being: The Political Thought of Martin Heidegger. New York: Columbia University Press.

1992. "Carl Schmitt: The Conservative Revolutionary Habitus and the Aesthetics of Horror." Political Theory 20 (3): 424-47.

. 1996. "Left Fascism: Georges Bataille and the German Ideology." Constellations 2:397-428.

Zimmerman, Michael E. 1990. Heidegger's Confrontation with Modernity: Technology, Politics, and Art. Bloomington: Indiana University Press.

Žižek, Slavoj. 1997. "Multiculturalism, or, the Cultural Logic of Multinational Capitalism." New Left Review 225:28-51. 